IZA DP No. 7524

The Effect of Public Wages on Corporate Compensation in Hungary

Álmos Telegdy

July 2013 


\title{
The Effect of Public Wages on Corporate Compensation in Hungary
}

\author{
Álmos Telegdy \\ CERS, Hungarian Academy of Sciences, \\ CEU and IZA
}
Discussion Paper No. 7524
July 2013

IZA
P.O. Box 7240
53072 Bonn
Germany

Phone: +49-228-3894-0

Fax: +49-228-3894-180

E-mail: iza@iza.org

Any opinions expressed here are those of the author(s) and not those of IZA. Research published in this series may include views on policy, but the institute itself takes no institutional policy positions. The IZA research network is committed to the IZA Guiding Principles of Research Integrity.

The Institute for the Study of Labor (IZA) in Bonn is a local and virtual international research center and a place of communication between science, politics and business. IZA is an independent nonprofit organization supported by Deutsche Post Foundation. The center is associated with the University of Bonn and offers a stimulating research environment through its international network, workshops and conferences, data service, project support, research visits and doctoral program. IZA engages in (i) original and internationally competitive research in all fields of labor economics, (ii) development of policy concepts, and (iii) dissemination of research results and concepts to the interested public.

IZA Discussion Papers often represent preliminary work and are circulated to encourage discussion. Citation of such a paper should account for its provisional character. A revised version may be available directly from the author. 


\section{ABSTRACT \\ The Effect of Public Wages on Corporate Compensation in Hungary ${ }^{*}$}

I identify wage spillovers from the public to the corporate sector with the help of a large and sudden public sector wage increase, which raised real compensation by 40 percent in two years, changing the average public wage premium from minus 10 to plus 12 percent. Using a dataset covering about 7 percent of Hungarian workers and their employer, the spillover effect is identified with the variation of the share of public sector employment within groups defined by gender, experience and occupation. The analysis shows that 10 percent higher share of public sector workers within worker-type induces an additional wage growth of 15-20 percent around the wage increase. Controlling for firm (worker spell) fixed effects does not change the results qualitatively and results in a spillover effect of 11-14 (7.5-12) percent. The spillover effect is positively correlated with the public wage premium within worker type, with occupations which are abundant in the public sector, with the availability of public sector jobs and being hired after the wage increase.

JEL Classification: J31, J45

Keywords: $\quad$ wage spillover, public sector, Hungary

Corresponding author:

Álmos Telegdy

Central European University

Nador 11, room 413

Budapest

Hungary

E-mail: telegdya@ceu.hu

\footnotetext{
* I thank John Sutherland Earle, Péter Elek, Gábor Kézdi, István Kónya, Miklós Koren and János Köllő for useful advice, John Harbord for editorial assistance and Márk Kovács and Szilvia Téglás for excellent research assistance. The data used in this paper were cleaned by a large number of research assistants, including Rita Petö, Péter Révész and the team of the Data Sources Department of the CERS. This research was supported by Grant No. 78,255 of the Hungarian Scientific Research Fund. The paper benefited from presentations at the Yearly Conference of the Hungarian Economic Association (2012), the Seminar Series of the CERS Labor Market Group, the Lunch Seminar Series of the CEU Economics Department and the $12^{\text {th }}$ Journées Luis-André Gerard-Varet (2013). All errors are my own.
} 


\section{Introduction}

The interaction of public and corporate wages has largely been neglected by research in past decades, even though public wage spillovers may be an important ingredient of the level and distribution of wages. ${ }^{1}$ If public and private sector workers compete on the same labor market, corporate employees may view the public sector as an alternative to their current employer. If total compensation, including the net value of amenities and disamenities derived from various job attributes, is high in the public sector, private employers may face difficulties in the hiring process or have to cope with high quit rates among incumbent employees. To prevent such mechanisms from taking place, they have to increase wages to be successful in hiring and to prevent their current employees from moving to the public sector. Such spillovers may affect not only the level of earnings but relative wages as well: employees who facing a high public sector demand and are also willing to become public sector employees will likely experience larger wage spillovers than their colleagues with different skills not valued in public sector jobs.

The estimation of wage interactions between two sectors of the economy is notoriously arduous. The typical research design of spillover analysis consists of computing correlations between the wages of workers of similar observable characteristics across units of observation (firms, regions, or sectors of activity) where the proportion of employees covered by the studied institution (unions, minimum wage, foreign ownership or the public sector) varies across the units of observation. This method, however, is subject to a series of biases: the compensation of workers may be correlated for a multitude of reasons, such as comovements of earnings of similar types, the effects of a common economic background and shocks idiosyncratic to a certain worker-type (Manski, 1993). In addition, the self-selection of workers into one or the other state which materialize not only along observable, but also unobservable characteristics makes difficult the comparison workers of the same marginal productivity (Roy, 1951).

\footnotetext{
${ }^{1}$ A thorough review of the literature revealed only one paper analyzing public wage spillovers with individual data (Jacobsen, 1992) while Lacroix and Dussault (1984) estimate the spillover effect on a dataset covering wage agreements. Another strand of literature studies at the macro level whether the government is wage leader, or simply follows the wage setting in the private sector (e.g, Demekas and Kontolemis, 2000; Lamo et al., 2012). The small number of papers on this topic is in contrast with the interest that other types of wage spillovers attracted: see, for example, the effect of minimum wage levels on higher earnings (Lee, 1999; Dickens and Manning, 2004), the degree of unionization on non-unionized workers' wages (Kahn, 1998; Vroman, 1982), the interaction between foreign and domestically-owned enterprises' wage setting (Aitken et al., 1996; Driffield and Girma, 2003) and inter-industrial and inter-occupational spillovers (Black et al., 2005; Latreille and Manning, 2000).
} 
These identification problems are present in the case of public wage spillovers as well. Public sector employees work fewer hours, enjoy longer paid vacation, have more secure jobs, lower required effort and worker motivation and job satisfaction may also differ across the two sectors (Delfgaauw and Dur, 2008; Heywood et al., 2002). Workers self-select themselves into one or the other sector based on their innate ability, risk aversion, willingness to work hard in exchange for higher wages and faster promotions, characteristics which are all unobserved by researchers (Borjas, 2003a). ${ }^{2}$ Public sector workers cluster in few industries predominantly in state administration, health care and education - where the share of corporations is negligible, making it impossible to control for industry wage effects, which may be sizable (Du Caju et al, 2010; Krueger and Summers, 1988). In addition, workers whose characteristics are akin to each other's tend to have similar wages (or occupy similar positions in the distribution of wages within sector). All these factors create substantial identification problems for the interaction of public and private sector wages: to identify a causal relationship, an exogenous variation of public sector wages is necessary.

The Hungarian institutional context is particularly useful in analyzing public wage spillovers as it provides the exogenous variation which makes it possible to overcome many of these identification problems, and thus the effect of public wages on corporate earnings can be measured more accurately than is usually possible. In 2001 and 2002, the Hungarian government executed a two-step wage increase in the space of about one year, resulting in an unprecedented increase of public sector real compensation by 40 percent. During this period, corporate wages increased by only 12 percent, leading to a change in the public wage premium from -10 to 12 percent. The sudden large wage increase in the public sector improved the outside options for corporate employees: ceteris paribus, corporate employees suddenly faced a more attractive alternative to their current job than before, which put pressure on corporations to increase wages. ${ }^{3}$ This unprecedented increase in public sector wages provides a unique opportunity to identify wage spillovers, as many of the problems listed above attenuate, to say at least. The exogenous wage increase breaks co-movements

\footnotetext{
${ }^{2}$ These differences also materialize in diverse wage levels in the two sectors (e.g., Dustmann and Soest, 1998; Gyourko and Tracy, 1988; Tansel, 2005). Other reasons for different wage levels can be divergent wage setting mechanisms, such as less frequently used incentive payment schemes in the public sector (Corneo and Rob, 2003), the lobbying of various state-owned agencies (Borjas, 1980), or high public sector wages as a result of the vote maximizing behavior of politicians (Shleifer and Vishny, 1994).

${ }^{3}$ Cahuc et al. (2006) model on-the-job search by assuming that this is a three-way bargaining between the employee, the current employer and an alternative employer who makes an outside offer. In the present case this outside employer is the Hungarian State, which increased its outside offer by 40 percent to those corporate employees who were similar to public sector workers. Current employers may raise wages even if actual mobility does not take place between the two sectors due to threat effects (see Borjas et al. (1997) on threat effects in the context of international trade and Farber (2005) of unionization).
} 
between public and private sector wages. The sector-specific differences discussed above, which may bias the estimation, do not present a problem here, as it is unlikely that the composition of workers (both by observable and unobservable characteristics), job attributes or industrial wage differentials changed considerably in such a short period of time.

The dataset used in this paper consists of a random sample of 6-8 percent of the workforce of Hungarian corporations with at least 5 employees (100-150 thousand individuals each year). To construct the spillover variable, we merge these data with another dataset including more than two-thirds of public sector employees. The corporate data are a panel in firms which is used in the identification. Although workers are not followed in time, a large number can be linked across years if they do not change workplace. These joint firm-worker spells are also used in the analysis.

The identification strategy combines the methodology used in earlier public wage spillover studies (Jacobsen, 1992) and the methods developed for the analysis of the effects of migration on native's wages (Borjas, 2003b). The labor market is segmented by gender, occupation, and labor market experience. Assuming that individuals of similar observable characteristics are close substitutes, I proxy the "closeness" of a corporate worker to the public sector by the share of public sector employment within these labor market cells. ${ }^{4}$ The correlation between corporate wage changes around the public sector wage increase and the share of the public sector within labor market cells provides a measure of the spillover effect. The regression controls for worker characteristics, region, sector of activity, year effect to partial out economy-wide shocks, firm-fixed effects in some regressions to control (at least partially) for firm level wage policies and non-observable job characteristics. The firm fixed effects are also useful to control for changes in the sample. In another set of specifications I replace firm fixed effects with worker-firm spell effects to partial out any individual and firm characteristics which are correlated with wages and fixed in time. All the regression results find a positive and statistically significant wage spillover effects: a 10-percent difference in the exposure to the public sector generates a faster wage growth ranging from 7.5 to 20 percent, depending on the specification used. The analysis also provides evidence that the relation between the share of public sector workers and corporate wages is remarkably stable before and after the public sector wage increase, and changes only in the years when the wage increase took place.

\footnotetext{
${ }^{4}$ This assumption is similar to the one made by Teulings (2000, 2003), who, when modeling the effect of minimum wage changes on the overall wage distribution, finds that the elasticity of substitution between two workers declines with the distance between their levels of human capital.
} 
Although the identification method reduces (or potentially eliminates) the comovements of wages in the two sectors which contaminate most research on spillovers, another potential bias can arise if the public wage increase overlapped with some other event which altered wage differentials and is spuriously correlated with the share of public sector workers. If, for example, the relative wages of those workers increased who are abundant in the public sector for a reason other than the public wage increase, the regression estimates are biased. To test for this possibility, I test how the relative wages change of two worker types which are present in large shares in the public sector: females and high-skilled occupations. The results do not show large changes in the gender wage gap and skill premium, so the hypothesis that the regression coefficients take up such effects can be rejected.

In addition to establishing the average spillover effect, I also analyze how it varies across labor market sectors and worker types. To start with sector-specific differences, the spillover effect should vary not only by exposure to the public sector but also by the wage differentials between the two sectors and the availability of new jobs in the public sector. Regarding worker types, those in occupations which abound in the public sector do not lose their job specific human capital if they switch (e.g., Kambourov and Manovskii, 2009), so they should be more willing to move across sectors and thus should get a larger wage increase to be induced to stay. Additionally, workers who start a new job after the wage increase should have a larger spillover, as in their case switching sector is a real option. By interacting measures of these worker and labor market characteristics with the measure of spillover, I establish how the effect varies along these dimensions.

Below, I present the data used in the analysis, followed by a description of the public and corporate labor markets, including worker composition and the evolution of wages. I then describe the methodology used and present the results concerning the average spillover effect and the heterogeneity. The last section concludes.

\section{Data Description}

The dataset used in this study is the Hungarian Wage Survey Data, hosted by the National Employment Office. It provides yearly information on workers' year of birth, gender, occupation, earnings, tenure and type of contract (corporate and two types of public sector labor relations, as discussed below). These data are recorded for May of each year. I use the years between 1998 and 2007 in this paper.

The sampling procedure of corporate employees is based on firm size. Each firm is required to send its employment level to the data host, and those having more than 20 workers 
have to report on all production workers born on the $5^{\text {th }}$ or $15^{\text {th }}$, and non-production workers born on the $5^{\text {th }}, 15^{\text {th }}$, and $25^{\text {th }}$ of any month. These data are augmented with a random sample of smaller firms, which are asked to provide information on all their employees. In 1998 and 1999 employers with 11-19 workers were sampled while for the latter years the sampling threshold was reduced to firms with 5 employees. Starting with 2002, firms with employment size below 50 were required to provide information on all their employees.

The public sector data include information on the employees of the organizations which are directly subordinated to ministries or the local administration. By their legal status, two types of public sector employees are used in the analysis: public employees and civil servants. ${ }^{5}$ Public employees constitute the bulk of public sector workers, as most of the employees in state administration, public healthcare and education work under this labor contract. Civil servants make up about 15 percent of the public employment sample. They are typically middle or high-ranked managers working in state administration, but in some organizations all employees possessing at least a high school degree have this legal status. Most public sector organizations use a centralized accounting system, and the data provide information on all of their employees; for the units which did not use the centralized system, the sampling procedure is identical to that used in corporations. ${ }^{6}$

The data also provide information on the number of production and non-production workers for each firm/public sector organization, thus permitting the construction of weights to correct for the sampling differences of production and non-production workers within firms/organizations. To correct for the different sampling in the public and corporate sectors and to weight the data up to the level of the national economy, I gathered yearly information from the website of the Hungarian Statistical Office on the number of public sector employees in the three main sectors of activity (health care, education and state administration) and a residual category including all other activities. The corporate data are weighted up to the total employment of a firm-level dataset hosted by the National Tax Authority, which contain all double-entry book keeping firms. ${ }^{7}$

The corporate data contain over 29 thousand firms which have been in the data for varying lengths of time. The average number of years a firm is followed is 3.1 , but 6,000

\footnotetext{
${ }^{5}$ The police, the military, firefighters and border guards are not included in the data, and I excluded the legal professions as their employment relation is regulated by a special law, and they were not subject to the wage increase. The workforce of state-owned enterprises is regulated by the general labor law and thus they are included in the corporate sample.

${ }^{6}$ I tried to identify regularities regarding the organizations using the centralized accounting system but did not find any.

${ }^{7}$ See Earle et al. (2012) for a description of the National Tax Authority dataset.
} 
firms are present for at least 5, and 3,500 for at least 7 years. Workers do not have a unique identifier but based on their time invariant characteristics they can be linked in time unless they switch employer. Using this procedure it is possible to follow 238 thousand workers for at least two years and 94 thousand workers for 3 or more years. To regain the random sample of workers, I construct individual weights based on the proportion of the workers included in the linked sample.

I keep in the sample only full time employees between 18 and 60 years. Table 1 provides the number of individuals in the public and corporate samples as well as the total employment of the relevant populations (which is the weighted sum of the samples). The final data include 379-487 thousand public sector employees and 106-153 thousand corporate workers. After weighting we obtain the aggregate employment numbers corresponding to the national economy. In the studied period there were about 680-720 thousand public employees and civil servants and 1.85-1.99 million corporate employees in the sampled population. The comparison of the unweighted and weighted employment numbers reveals that the sample of corporate and public sector employees makes up about 7 and 70 percent of the population, respectively.

\section{Composition of Employment and the Evolution of Wages in the Public and Corporate Sectors}

\subsection{Composition of the Public Sector and Corporate Employment}

The descriptive statistics of public and corporate employment for the pooled sample are presented in Table $2{ }^{8}$ Three-quarters of public sector workers are female, which is almost twice as large a share as in corporations. Corporate employees' potential labor market experience (equal to age - years of education - 6) is shorter by two years. ${ }^{9}$ The categorical variables showing the proportion of workers in 5-year intervals by experience reveal that workers with less than 15 years of experience have a lower, while older workers have a higher share in public sector employment.

Given the peculiar industrial structure of the public sector, it is not surprising that the occupational distribution of employees is very divergent in the two sectors. Professionals and associate professionals are the most typical workers in the public sector: 60 percent of all

\footnotetext{
${ }^{8}$ Worker characteristics vary in time to some extent as presented in Table A1 in the Appendix, but the changes are not large and they are rather smooth, making it unlikely that they are a result of the public sector wage increase.

${ }^{9}$ The computation of the potential experience variable was based on the average years necessary to obtain 9 different degrees.
} 
employees work in such occupations. This is in sharp contrast to such occupations' share of 20 percent in corporations. As expected, skilled workers are the most typical employees in the corporate sector, with 46 percent of all occupations in this category, compared to only 6 percent in the public sphere. Managers' share in the corporate sector is 9.5 percent, 1.5 percentage points higher than in the public sector. Elementary occupations have a share of 14 percent in the public sector, almost twice as high as in corporations.

The database has two measures of tenure. The first is a dummy variable which equals 1 if the worker was hired during the previous calendar year. The second is tenure measured in years, which is available only since 2002. The proportion of newly hired workers in a year relative to the total population of the sector is 9 percent in the public sector and 13.6 percent in corporations, suggesting that there is less churning taking place in the public sector. ${ }^{10}$ The length of tenure also demonstrates that workers are less mobile in the public sector than in corporations: the average tenure is close to 11 years, which is much larger than the 8 years associated with corporate workers.

\subsection{Wage Policies and Wage Patterns in the Public and Corporate Sectors}

The period between 1998 and 2007 is characterized by a steady growth of the Hungarian economy. Gross domestic product (GDP) grew each year between 3 and 5 percent except in the last year of the analysis when it stagnated (Hungarian Statistical Office). Private wages followed this pattern, as documented below. Public sector wages, however, presented a more volatile behavior, which was probably caused by the need to increase them relative to corporate wages and partly by political considerations.

Wages in the public sector are determined by a wage grid, which consists of a base wage and multipliers. Total compensation can be larger than specified by the wage grid if the worker receives allowances (such as a managerial allowance or language allowance), and public sector organizations are also entitled to paying a higher wage if they have the necessary resources - these materialize in the form of regular extraordinary payments and irregular bonuses. Public sector employees also received a thirteenth monthly salary based on their base wage during the period studied.

The first attempt to foster changes in the lagging compensation in the public sector targeted civil servants, who make up about 15 percent of all public sector employees in the sample. Within the program called "civil servant life-long career," their wages were raised

\footnotetext{
${ }^{10}$ This figure refers to newly hired workers during a calendar year who were still with the firm/organization the following May, when the survey was done.
} 
significantly, but the emphasis was placed on providing incentives to remain a civil servant throughout one's whole career. The base wage increased only little from year to year, but the wage grid was made significantly more unequal, favoring university graduates and experienced workers. ${ }^{11}$

Between 1998 and 2002, public employees' earnings were increased only to the extent of keeping their wages stable relative to corporate earnings. Low average wages, however, put pressure on governments to increase public sector compensation and in September 2002 the base wage was increased by 50 percent from one day to the next. ${ }^{12}$ During the following four years the wage grid changed only in 2005 and 2006 . $^{13}$

The wage measure used in this paper is the monthly wage paid in May, and it includes the base wage, overtime pay, regular payments other than the base wage (such as language and managerial allowances), and one twelfth of the previous year's irregular payments (e.g., end-of-year bonuses and the $13^{\text {th }}$ salary in the public sector). ${ }^{14}$ If the worker was hired during the previous year, the last wage component is not divided by 12 but by the number of months the worker spent with the company in that year.

Figure 1 presents the wage levels and growth in the two sectors. During the first four years of the analysis public sector employees had indeed very low wages. Despite the much larger share of high skilled employees in the public sector, average wages were 10-15 percent lower between 1998 and 2001. ${ }^{15}$ The second panel of the figure shows that corporate real wages increased steadily by 3-6 percent each year (except in 2004 when they did not change) but wages in the public sector followed a distinctly different pattern. In the first three years of

\footnotetext{
${ }^{11}$ Between 1998 and 2001, the least and most experienced workers with a university degree had a wage multiplier of 1.25 and 3.4 respectively. In July 2001 these were raised to 1.84 and 5.22, and one year later they were further increased to 2.10 and 6.00. After 2004, the most inexperienced civil servants' wage multiplier was increased again to 3.10. During the same period, the multipliers of civil servants with only high school diploma also increased from 1.00/2.40 to 1.60/4.40 by 2006. The wages of civil servants are not directly determined by the base wage, as different organizations use multipliers which vary between 10 and 80 percent.

${ }^{12} 2002$ was an election year and public sector wages were a major theme of the campaign. After the elections a political scandal erupted. To restore credibility (and perhaps increase popularity) the government fulfilled its promise right away, which materialized in a program labeled "the 50 percent public sector wage increase."

${ }^{13}$ During the period studied, minimum wages also changed radically, from Huf 25,000 in 2000 (28 percent of the average wage) to Huf 40,000 in 2001 and one year later to Huf 50,000 (40 percent of average wages). The effects of the minimum wage increase are not the focus of this paper, but they may affect the results (in 2000, 27 percent of public sector employees had wages lower than the new minimum wage). I take this into account in the robustness checks of the analysis. See Kertesi and Köllő (2003) for an analysis of the employment and wage consequences of the minimum wage increase.

${ }^{14}$ As the data allow us to follow only a subset of workers across years, it is not possible to add the current year's non-regular payments to the wage. For the workers followed for multiple years, the correlation of irregular payments between two consecutive years is around 70 percent except the last year of the analysis when it is only 38 percent.

${ }^{15}$ While studies of public-private wage differentials usually find a public wage premium in developed countries (Gregory and Borland 1999), a negative wage differential is common in Central and Eastern Europe (see Adamchik and Bedi (2000) for Poland and Gorodnichenko and Sabirianova Peter (2007) for Ukraine).
} 
the analysis the overall growth rate is quite similar in the two sectors, but in 2001 they grew by 15 percent. This is followed by an increase of 22 percent in 2002, which is more than five times larger growth rate than of corporate compensation. ${ }^{16}$ The data therefore demonstrate that in a two-year time period real wages in the public sector increased by 40 percent while those in corporations by only 12 percent. In the last years of the analysis the growth rates in the two sectors follow divergent patterns with a decline of public real wages in the last year of the analysis.

What is the effect of this wage increase on the public sector wage premium? Figure 2 summarizes the evolution of the relative wages between the two sectors. The figure presents the average public wage premium and its disaggregation by worker characteristics. Between 1998 and 2001 average relative wages were quite stable with a negative public wage premium of 10-15 percent, as the first graph demonstrates. After the two years of the public wage increase, relative wages changed such that the public wage premium became plus 14 percent in 2004. In the subsequent period relative wages decrease somewhat, with quite a large drop in the final year.

The other panels of the figure present the public sector wage premium by gender, experience and occupation. Female relative wages are lower than male wages before the wage increase and become identical afterwards. Public sector workers with fewer than 20 years of work experience are more disadvantaged than older employees and their relative position does not change after the wage increase. The public wage premium by occupations reveals that professionals and associate professionals - the two occupational categories which require high skills and make up the bulk of public employment - have the lowest relative wages: before the wage increase the earnings of such public sector workers were only half as high as in corporations. The highest relative wages are identified for low skilled workers with service and elementary occupations. It is worth noting that that the public sector wage increase did not change the relative position of workers along the studied variables, with the sole exception of managers.

\section{Identification Strategy}

The methodology of this paper follows Jacobsen (1992), who identified the effect of public wages on corporate compensation by measuring the correlation between the share of

\footnotetext{
${ }^{16}$ The wage policy of 2002 was labeled as a 50 percent increase, but it was not applied to public functionaries and referred to the base nominal wages. We computed the growth of nominal base wages for public employees between 2002 and 2003 which is indeed very close to 50 percent.
} 
public sector in occupational categories. The present analysis builds on, but also extends this approach by borrowing from the literature on the effects of migration on native workers' wages (Borjas, 2003b) by taking into account work experience as well. In addition, it also segments the labor market by gender, as the descriptive statistics presented in Table 2 above demonstrate that the share of females is high in the public sector. Thus, the variable measuring public sector proximity of a corporate employee is the proportion of public sector workers in labor market cells defined by gender, occupation and work experience. ${ }^{17}$ More precisely, I segment the labor market by gender, potential labor market experience (5-year intervals making up 8 groups) and 7 occupational dummies (as shown in Table 2), which segment the labor market into 112 cells each year. The variable used to proxy for the exposure (or similarity) of a corporate worker to the public sector is Pshare $_{j t}$, representing the proportion of public sector workers within labor market cell $j$ in year $t$ :

$$
\text { Pshare }_{j t}=M_{j t}\left(M_{j t}+N_{j t}\right) \text {, }
$$

where $M_{j t}$ and $N_{j t}$ are the number of public and corporate workers in gender-experienceoccupation-year cells. ${ }^{18}$

The use of this variable as a measure of the spillover effect hinges upon a set of identifying assumptions. First and most important, the potential and also the willingness to become a public sector worker should be an increasing function in Pshare. For this note that Pshare is likely to be influenced both by the demand for various types of workers in the public sector, and also by the self-selection of workers into public sector jobs. The occupational structure is a good example of the demand effect, and the large proportion of females in the public sector can also be the result of the large share of "female-type" occupations. Females, however, may also choose the public sector for other reasons, such as more flexible working time or less competitive environment to share their time between market and household work. The public sector wage premium may also be a factor in determining which workers choose public sector jobs: as discussed in Section 3, experienced workers are more likely to work in the public sector, but these employees also have larger relative wages than their younger colleagues. Therefore, Pshare embeds the demand for, and the willingness to work in the public sector of different types of workers. If public sector wages increase, the marginal corporate worker in a labor market cell with a large share of

\footnotetext{
${ }^{17}$ We use broad occupational categories rather than education as this variable takes up the specific human capital of different occupations to a greater extent and it also results in a larger number of labor market cells than the four educational categories.

${ }^{18}$ Some cells contain only few workers and thus the share of public sector is not measured well, but all the regressions are weighted and thus they do not contribute much to the estimation.
} 
public workers will be more likely to find a job, and also be more willing to switch to the public sector than those who are not of such worker type. To prevent their employees' from separation and to attract workers to their firm, corporate employers have to match the wages of such workers closely with the compensation in the public sector.

The second identifying assumption is that no change other than the public sector wage increase should take place in the economy which is correlated both with corporate wages and Pshare. If such a change happened during the public wage increase, then Pshare may take up this, and not the spillover effect. One candidate for such a contaminating effect is the composition of public sector labor force, both by observables and unobservables. If the wage increase induces changes in composition, the Pshare variable may represent different populations before and after the wage increase. The results may also be biased if corporate wages changed during the wage increase along gender, experience and occupation, variables which were used to construct Pshare. In addition, almost overlapping with the public sector wage increase, the minimum wage was also substantially increased, which could change wage differentials in such a way that those workers with large Pshare obtained larger wages. As I discuss below, I provide some tests to rule out these biases.

In the first identification of the public wage spillover effect, I regress the log of corporate sector wages on Pshare, which is interacted with two periods of time: Before (=1 for the period of 1998-2001) and After (=1 for 2002-2007). To control for average wages by worker type, I include fixed effects of the variables used in the construction of Pshare ${ }^{19}$ as well as year effects, 21 regional (county) effects and a full set of two-digit industries to control for country, regional and industry-specific shocks, as well as to partial out any differences between local labor markets, and industrial wage differentials. As the level of public sector wages may also affect the strength of the spillover, I also control for the average public sector wage within labor market cells $\left(w p_{j t}\right)$. The unemployment rate at the cell level $\left(u e_{j t}\right)$ is included as well, as it can also affect spillovers: if there are many unemployed, the bargaining power of workers declines and they cannot negotiate for higher wages, regardless of the proximity of the public sector (Blanchflower and Oswald, 1990). ${ }^{20}$

Some firms employ a higher proportion of public type workers and wages also depend on the employer (Abowd et al., 1999), and such firms may raise wages faster than the average

\footnotetext{
${ }^{19}$ I do not control for a joint cell effect, because the variation used for the identification of the spillover effect (the share of public sector in total employment) varies little over time. Adding cell fixed effects would take out all the important variation from the data.

${ }^{20}$ The unemployment rate is not available at such disaggregated level, nor can it be computed by occupations. Rather, it was computed for gender-experience-education categories with the help of the Hungarian Labor Force Survey.
} 
corporation, creating a spurious correlation between wages and Pshare. To attenuate this potential bias, I also add firm-level fixed effects (FE) to some specifications. Firm fixed effects are also useful to control - at least partially - for non-pecuniary benefits, which contribute to the overall compensation but are not embedded in the wage variable. In addition, firm fixed effects control for the variation of the sample of firms across time. In this specification the spillover effect is identified from the variation of Pshare between workers employed by the same employer before and after the public sector wage increase. The inclusion of firm fixed effects comes at a cost, however. As the data do not comprise the population but only a sample of workers, in many cases only few are observed within firm and so adding firm fixed effects to the regression greatly reduces the variability of worker characteristics. This presents a problem when we slice the sample by these characteristics to shed light on the heterogeneity of the effect.

The data also allow the inclusion of firm-worker spell effects (WE) for a subsample of workers whom it is possible to link across years. These have the advantage of taking out worker unobserved characteristics which may be correlated with wages. When worker effects are added, the identification comes from those workers who are observed both before and after the wage increase. While this identification method is useful to obtain estimates which are not biased by unobserved individual characteristics if the pool of workers changes, the number of workers who are present both before and after the wage increase is relatively small. $^{21}$

The most parsimonious estimation equation is the following:

$$
\begin{aligned}
& \log \left(w_{i j t}\right)=\alpha_{0}+\gamma_{\text {before }} \text { Pshare }_{j t} \text { Before }_{t}+\gamma_{\text {after }} \text { Pshare }_{j t} \text { After }_{t}+\alpha_{w p} \log \left(w p_{j t}\right)+ \\
& \alpha_{u e} \log \left(u e_{j t}\right)+\alpha X_{i j t}+\sum \alpha_{i n d} \text { Industry }_{k}+\sum \alpha_{\text {reg }} \text { Region }_{r}+\sum \alpha_{t} \text { Year }_{t}+u_{i j t}
\end{aligned}
$$

If the assumptions stated above are valid, the estimated spillover effect is $\gamma_{\text {after }}-\gamma_{\text {before }}$. I also run specification (2) with a full set of interactions between Pshare $e_{j t}$ and year dummies instead of two aggregate time periods, to gauge the dynamics of the spillover effect.

The analysis above assumed a linear functional form of the wage spillover effect along the values of Pshare. Now I relax this assumption to test the effect of the functional form on the results and also to observe how the spillover effect varies by public sector exposure. In this second specification I use the cross sectional variation of Pshare more explicitly and compute the difference between the wage change in labor market cells with high and low exposure to the public sector before and after the wage change. I do this by replacing Pshare

\footnotetext{
${ }^{21}$ There are 22 thousand workers observed for all the three years between 2001 and 2003 and 49 thousand workers who are observed for two years in this period.
} 
with five dummies, each representing one quintile of the variable (this specification in fully non-parametric). To add year effects to the regression as controls, I drop the variable representing the first quintile each year which consists of labor market cells with Pshare close to zero. The difference between wage changes in labor market cells with high and low public sector exposure before and after the public wage increase provides a measure of the spillover effect. This specification is also used to run "pseudo-tests:” to check whether we can obtain a change in the spillover effect for time periods other than when the public wage increase took place. For this I compute the wage changes by Pshare quintile between 1998-2001 and 20042006.

A potential source of endogeneity which may contaminate the estimates is that changes in the economy (other than the public wage increase) increased the relative wages of those workers who have a high exposure to the public sector. For example, if female corporate employees experience a wage increase which is not caused by the proximity of the public sector, Pshare may take up this effect since it is correlated with the share of females (the same reasoning applies to workers in occupations requiring high skills). To test for this possibility, I rerun regression (2) but with Pshare replaced with a dummy variable $=1$ if the worker is female. I test for changes in the skill premium in a similar fashion, using a dummy variable $=1$ if the worker has an occupation requiring high skills (professional and associate professional). If the difference between the interaction of Female (High skill) and Before and After is similar to what we obtain when Pshare is interacted with the two time dummies, the results are likely to be driven by wage increases of these groups, and not by the wage increase in the public sector. ${ }^{22}$

An institutional change which may also cause a bias in the estimation of spillover effects is the increase of the minimum wage, which took place right before the public wage increase (in January 2001). To test for the possibility that the spillover effect is contaminated by the minimum wage increase, I run the regression on the sample of those corporate workers who earned at least 5 percent more than the prevailing minimum wage, as this sample is less likely to be influenced by minimum wage increases.

Wage spillovers do not depend only on the exposure of a corporate worker to the public sector, but also on other factors, at the individual or labor market cell level. Following the measurement of the average spillover effect, I turn now to the analysis of the heterogeneity of the spillover effect along such dimensions. To start with wages, it is likely

\footnotetext{
${ }^{22}$ These regressions are not estimated with WE. This would be impossible for gender while for high skill it would identify the effect only from switchers across occupations, which is likely to be a selected sample.
} 
that not only public sector exposure, but also the wage differential between the public and corporate sectors matter: the larger it is, the better the outside option of a corporate worker (Cahuc et al, 2006). If wages exhibit downward rigidity (e.g., Goette et al., 2007; Fabiani et al., 2010), then it is also likely that those with wages higher than the public wage level are less likely to switch sector. I test this by interacting the average public sector wage within labor market cell with Pshare and the two time period dummies.

I also test the effects of occupations. Workers in occupations which are abundant in the public sector should have higher wage spillovers as they do not lose their occupationspecific human capital when switching sector. I construct a dummy variable which equals 1 if the public sector presence within occupation (defined at the 3-digit level) is larger than 40 percent, and I interact this with Pshare before and after the wage increase.

Third, I also test whether the spillover effect varies by the proportion of vacancies in the public sector (the more vacancies there are, the easier is to find a job in the public sector). I create a variable which measures the share of public sector new hiring relative to the size of the corporate labor market within cell. The estimation equation is the same as before, but I do not interact this variable with Pshare as it is already proportional to the corporate sector. ${ }^{23}$

Finally, those corporate workers who were hired after the wage increase should experience larger wage spillovers: as they switched jobs, they had a real choice of moving to the public sector, and thus the wage spillover should be larger in their case than for workers who stayed with their employer. The tenure variable exists only starting with 2002 and allows us to compute a variable which indicates whether the person was hired before the public sector wage increase. I interact this variable with Pshare.

The estimation equation used to study the heterogeneity of the spillover effect is the following:

$$
\begin{aligned}
& \ln _{i j t}=\beta_{0}+\beta_{\text {before }} \text { Pshare }_{j t} \text { Before }_{t}+\beta_{\text {after }} \text { Pshare }_{j t} \text { After }_{t}+
\end{aligned}
$$

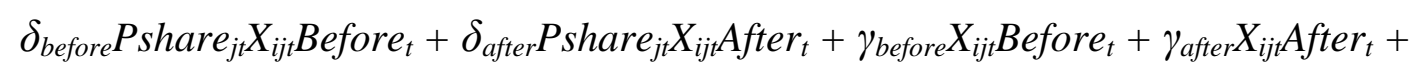

$$
\begin{aligned}
& \beta X_{i j t}+\Sigma \beta_{\text {ind }_{\text {Industry }}}+\Sigma \beta_{\text {reg }} \text { Region }_{r}+\Sigma \beta_{t} \text { Year }_{t}+\mu_{i j t},
\end{aligned}
$$

where $X_{i j t}$ is equal to the average public wage within labor market cell, a dummy variable indicating whether the worker's occupation is abundant in the public sector, the proportion of public sector new hiring relative to the size of the corporate sector, and a dummy variable

\footnotetext{
${ }^{23}$ The variable indicating whether someone is a new hire refers to the previous years, and so this regression does not contain the last year of the analysis.
} 
indicating whether the worker was hired after 2001. In addition to the control variables included in equation (2), I also include the level of $X_{i j t}$ for the two time periods separately. ${ }^{24}$

\section{Results}

5.1 Measurement of public sector exposure of corporate workers

The descriptive statistics of Pshare, are shown in Table 3. The average share of public sector workers is quite stable during the period studied: its mean value varies between 19 and 21 percent. The standard deviation is large relative to its mean, showing that the variable spreads over most of the interval it is defined over. Indeed, the minimum and maximum values confirm this tendency: there are some sectors where the share of public sector workers is close to zero while others are almost totally made up by them. To further investigate the variability of Pshare, I present its histogram for 2001 in Figure A1 in the Appendix. The distribution of Pshare follows a hyperbolic shape, with some mass point around the value of 0.5. Further investigation of the variable (shown in Table A2) reveals that the proportion of females is low in the least exposed cells and it is high in the most exposed labor market segments; years of experience do not seem to be in a strong relation with Pshare; and typical occupations in cells with low public sector share are quite variable, while segments with high public sector shares are predominantly employed by professionals and associate professionals.

The spillover results may be contaminated by selection bias if the public sector wage increase affected the composition of public sector workers. In this case the identifying assumption that the only variation in the public sector is the large wage increase no longer holds. I test this in several ways. First, I compute the correlations between the values of Pshare in different years. This correlation coefficient is the smallest for the years the most further apart, 1998 and 2007, when it is equal to 0.937; around the public sector wage increase (between 2001 and 2004) it is 0.980. Therefore, Pshare does not change much during the whole period studied.

For the validity of the analysis, however, it is also important that the distribution of unobservable characteristics did not change. There is no direct test to analyze this, but the observables do not change sharply around the public wage increase, as shown in Table A1. This suggests that unobservables are also unlikely to have greatly changed in the period of study (Altonji et al., 2005) and the continuity of the change during the whole period studied

\footnotetext{
${ }^{24}$ These regressions slice up the data to a great extent and I do not run them with worker effects. Even the firm fixed effects regressions should be interpreted with caution, as the within-firm sample of workers is quite small (as discussed in Section 2).
} 
makes it unlikely that these changes are caused by the public sector wage increase. The table also shows the proportion of newly hired workers, which is stable and does not go up after the wage increase (it actually declines somewhat). The fact that the hiring behavior of public sector organizations did not change after the wage increase also provides some indirect evidence that that the composition of workers changed considerably.

\subsection{Estimation of the average spillover effect}

The regression results of Equation 2 are presented in Table 4. The coefficients of the gender and occupational variables are highly significant, their magnitude being in the conventional range while experience seems to be correlated with other controls variables as the earnings-experience profile becomes very flat when the unemployment rate and public sector wage are added as controls. Column 1 contains the estimated coefficients with the OLS regression without controlling for public sector wage and the unemployment rate in the labor market cell. In this specification private wages do not vary by the exposure of workers to the public sector before the public sector wage increase (the coefficient associated with Pshare before the wage increase is only 0.02 and statistically insignificant). In the subsequent period the level of corporate compensation increases in the sectors exposed to the public sector: the estimated coefficient of Pshare after 2001 is as large as 0.136 and it is highly significant. Including the logarithm of average public sector wage and unemployment rate (presented in Column 2 of the table) decreases the coefficient before the public wage to -0.05 and changes only little the coefficient of Pshare after the wage increase, which takes a value of 0.127 . The inclusion of firm fixed effects provides a coefficient of 0.033 (insignificant) of Pshare before the public sector wage increase and increases it after the wage increase to 0.163. The inclusion of worker-firm spell effects considerably decreases the coefficient of Pshare before the wage increase which becomes -0.106 and highly significant, but the effect decreases after the wage increase as well to -0.02. Taking the difference between the coefficients associated with Pshare before and after the wage increase as a measure of the wage spillover, this analysis finds that during a period of a 40 percent increase of the public wage, a 10-percent difference in public sector exposure induced a larger wage growth of 0.91.8 percentage points, depending on the specification used. ${ }^{25}$ Compared to the 12 increase of corporate wages, these results translate to 7.5-15 percent faster wage growth.

\footnotetext{
${ }^{25}$ To test for the effect of extreme values of Pshare on the spillover effect, I ran Equation (2) without the labor market cells with very low and vary high values of Pshare, and the results do not change qualitatively.
} 
To gauge how the spillover effect evolves in time, we present the same regressions with a full set of interactions between years and Pshare (in the following we always control for public sector wages and the unemployment rate). These results are shown in Figure 3 and the coefficients and their standard errors are presented Table A3. In the first four years of the analysis, the coefficients of Pshare are in a narrow range within each specification with no visible trend. In 2002, one year after the start of the public sector wage increase, the effect of public sector exposure on corporate wages takes an upward trend and continuously increases until 2004 in the OLS and FE specifications; when worker effects are controlled for, the coefficient increases until 2003. In the subsequent years the coefficients are again in a narrow range, with some decline in the OLS specification. The difference between the coefficient in 2001 and 2004 is 0.24 in the OLS, 0.17 in the FE and 0.14 in the WE specification, which implies that workers associated with a ten percent higher Pshare experienced a higher wage growth by 20, 14 and 11 percent. The evolution of the spillover effect in time reveal that the interaction of wages in the two sectors was quite stable before the public wage increase, when relative wages did not change; it increased significantly during the public sector wage increase; and was stable again thereafter. ${ }^{26}$

In the second specification I replace Pshare with 5 dummies, each representing one quintile of the variable (the coefficients of all the quintile dummies and their standard errors are presented in Appendix Table A4). Figure 4 presents the difference in the coefficients of each quintile for different pairs of years for the three specifications. The solid lines represent the coefficients resulting from the OLS, the dashed lines from the FE and the dotted lines from the WE specification. Between 2001 and 2004 the magnitude of the wage increase is positively correlated with the order of the quintile in each specification (see the lines marked with points). For the second quintile the difference in the coefficients is 0.025-0.037 while for the fifth quintile it is $0.75-0.133$. The figure also shows that the spillover effect is relatively linear over the whole range of Pshare.

I also perform pseudo-outcome tests to check whether the effect is indeed related to the public sector wage increase. The unmarked lines and those with crosses represent the difference in the coefficients of the quintiles between 1998-2001 and 2004-2007, when the public sector wage premium was fairly stable. The correlation of the corporate wage increase with Pshare in these periods is fairly uniform along the quintiles of Pshare and it certainly

\footnotetext{
${ }^{26}$ In the last year of the analysis the public wage premium drops but the spillover effect does not; it is possible that the wage change took place at the end of that year and there was not time to adjust corporate wages. As there is no within-year data available on wages, this cannot be tested.
} 
does not present an increasing pattern. Thus, the analysis does not reveal "pseudo" spillover effects in the periods when there was no wage increase in the public sector.

How do our results compare with other studies' findings? As discussed in Section 1, only two studies were found which estimate the public wage spillover effect with the help of micro data. Jacobsen (1992) uses individual data from the United State and finds that the share of the public sector in occupations is positively correlated with private sector wages, the estimated effect being between 0.10-0.25, depending on the gender and race of the studied subpopulation. Lacroix and Dussault (1984) analyze the same question with Canadian data, and find that public sector wage agreements do increase the wages of the private sector by 4-5 percent.

One potential source of endogeneity is that corporate wages increased regardless of the public sector wage increase but in such a way that their growth is associated with Pshare, causing a spurious correlation between the wages of the two sectors. As Pshare is correlated with gender and skill, potential candidates for such effects are changes in the gender wage gap or the skill premium. To test for this possibility, I replace Pshare in Equation (2) with a female dummy and a dummy indicating whether the worker has an occupation which requires high skill (professional and associate professional). The coefficients of these variables are presented in Table 5 and show that the gender wage gap (skill premium) indeed declined (increased) by about 3-6 percentage points, but these changes are pale in comparison to the wage changes associated with Pubshare which is 3-4 times larger in magnitude and they may - at least partially - be caused by the spillover effect itself. Therefore, it is unlikely that the results are driven by changes in the wages of the groups which are the most exposed to the public sector.

Another possibility which may affect the analysis is the increase of minimum wages in the economy. To control (at least partially) for the effects of this policy change, I run the same regression as before but on the sample restricted to those workers whose wage exceeds the minimum wage by at least 10 percent. As the bottom panel of Table 5 demonstrates, the exclusion of low-wage earners from the analysis does not change the results qualitatively.

5.3 The effect of public sector wages, occupations, vacancies in the public sector and timing of hiring

I now turn to analyzing the variation of the spillover effect by the level of public sector wages, occupations, vacancies in the public sector and the timing of hiring in the private sector. Table 6 presents the difference in the effect of Pshare before and after the 
public wage increase, and also the difference of the effect of the variables of interest interacted with Pshare around the wage increase (the p-values associated with the t-tests of the difference between the two coefficients are in parentheses). ${ }^{27}$ To start with public sector wages, the regressions demonstrate that in those sectors where the average public wage was large, corporate wages grew fast: the difference between the coefficients of the interaction terms between Pshare and the mean wage before and after the wage increase is 0.074 or 40 percent of the measured main spillover effect of 0.19 . The FE result provides similar results but the relation between the spillover effect and public sector wages is insignificant. ${ }^{28}$

Wage spillovers may also vary along the occupational structure of the corporate sector. Workers with occupations which are abundant in the public sector are likely to have a higher wage increase, as they can find a job more easily and they will not lose their occupation-specific human capital if they move. To test this, I construct a dummy variable which categorizes each 3-digit occupation by its public sector share: the dummy equals 1 if this is larger than 40 percent. $^{29}$ The estimated coefficients, presented in column 2 of Table 6, indeed demonstrate that the spillover effect is larger for such workers. Occupations which are abundant in the public sector have 50-70 percent higher spillovers than those which are not found in great proportions in the public sector.

Another feature of the labor market which may alter wage spillovers is the proportion of new hires in the public sector. If there are no employment opportunities, corporate workers cannot switch sector and so the interaction of wages between the two sectors will be weak. I compute the rate of new hires in the public sector relative to the number of workers in corporations within labor market cell, and I add this variable to the regression. ${ }^{30}$ The results (presented in column 3 of the table) show that 10 percent more new hires in the public sector increase the spillover effect by 0.065 percentage points which is quite large relative to the main effect of 0.17 (the result is 0.027 in the fixed effects regression).

Finally, I look at the heterogeneity of the spillover effect between workers hired after the public wage increase and those employees who were with their employer already before the wage increase. For this I construct a variable which indicates whether the worker was

\footnotetext{
${ }^{27}$ The estimated coefficients and standard errors of Equation (3) are shown in Table A5. Pshare is demeaned in the interaction terms when the variable of interest is continuous so the main effect measures spillovers for the average value of the variable Pshare is interacted with.

${ }^{28}$ As discussed in the data and methodology sections above, the inclusion of FE greatly reduces the variation of worker characteristics within the unit of observation so these results should be treated with caution.

${ }^{29}$ Out of 136 occupations, there are 42 which satisfy this condition, and they cover 10 percent corporate workers.

30 This variable is not interacted with Pshare because it is proportional to it by construction. The average public sector hiring rate relative to private sector employment is 0.024 , with a standard deviation of 0.065 .
} 
hired after 2001. ${ }^{31}$ This variable is then interacted with Pshare and its level is also included in the regression. As the results presented in Table 7 show, the main spillover effect is similar to the results presented so far, but those workers who were hired after 2001 experience a wage increase of almost one percentage point when the specification is OLS (but this result is not reproduced in the fixed effects regression where this coefficient is zero). We have some partial evidence therefore that the spillover effect is stronger for those who changed jobs after the wage increase and thus had a real option of switching to the public sector.

\section{Conclusions}

This paper has measured public wage spillovers, using for identification a sudden and sizable public sector wage raise which increased the public wage premium from -10 percent to 12 percent in a two-year period. I argue that the external shock of public wages provides a quasi-experimental setting which reduces the identification problems arising when spillovers are estimated as co-movements of wages, self-selection of workers into public sector employment, and specificities of the two sectors do not change around the wage increase and therefore do not bias the spillover effect.

Measuring public sector proximity by the share of public workers in labor market cells defined by gender, labor market experience and occupation, the paper found that the wage differential induced by the proximity of the public sector induces a 15 percent faster wage increase for a 10 percentage points increase in public sector share. The inclusion of firm fixed effects and joint worker-firm fixed effects reduces the magnitude of the effect but it does not change the results qualitatively. Sectors with high public sector wages or with many job opportunities induce a larger spillover; workers whose occupation is prevalent in the public sector or were hired after the wage increase also experience larger spillovers. The analysis does not find any pseudo outcomes - wage increases correlated with the public sector share when the public sector premium did not change, nor wage increases which can be confounded with public spillovers, such as a decline in the gender wage gap or an increase of the skill premium.

These results can be interpreted in the spirit of Cahuc et al. (2006), who assume that on-the-job search can be thought as a three way bargaining between the employee, the current employer and an outside employer who makes a wage offer. In the case of Hungary, this outside employer was the State which increased its outside offer by 40 percent, affecting

\footnotetext{
${ }^{31}$ Tenure is not available for earlier years and so I cannot include its interaction with Pshare before the wage increase to the regression.
} 
predominantly those workers who were demanded by, and also willing to work in the public sector.

How costly was this wage increase for corporations? We cannot give a precise measure, but from the heterogeneity of the spillover effect we can compute an approximate value of the wage increase. Based on the FE estimation from Table 4, the total cost was Huf 7.5 Bln or 2.7 percent of the total wage bill in 2001; this figure is Huf 14.8 Bln (5.2 percent) when the estimates from Figure 4 are used. The analysis thus demonstrates that public wage spillover is an important mechanism through which the state intervenes in the labor markets of corporations indirectly, causing their wage costs to raise significantly. 


\section{References}

Abowd, John M., Francis Kramarz, and David N. Margolis (1999). "High Wage Workers and High Wage Firms.” Econometrica 67(2), 251-333.

Adamchik, Vera A., and Arjun S. Bedi (2000). "Wage Differentials between the Public and the Private Sectors: Evidence from an Economy in Transition.” Labour Economics 7, 203224.

Aitken, Brian, Ann Harrison, and Robert E. Lipsey (1996). "Wages and Foreign Ownership. A comparative Study of Mexico, Venezuela, and the United States.” Journal of International Economics 40, 345-371.

Altonji, Joseph G., Todd E. Elder, and Christopher R. Taber (2005). "Selection on Observed and Unobserved Variables: Assessing the Effectiveness of Catholic Schools.” Journal of Political Economy 113(1). 151-183.

Black, Dan, Terra McKinnish, and Seth Sanders (2005). "The Economic Impact of the Coal Boom and Bust.” Economic Journal 115, 449-476.

Blanchflower, David G., and Andrew J. Oswald (1990). "The Wage Curve." Scandinavian Journal of Economics 92(2). 215-235.

Borjas, George J. (2003a). "Wage Structures and the Sorting of Workers into the Public Sector.” In: For the People: Can we Fix Public Service? (J. Donahue, J. Nye eds.), Washington, D.C.: Brookings Institution Press.

Borjas, George J. (2003b). "The Labor Demand is Downward Sloping: Reexamining the Impact of Immigration on the Labor Market.” Quarterly Journal of Economics 118(4), 13351374.

Borjas, George J. (1980). "Wage Determination in the Federal Government: The Role of Constituents and Bureaucrats.” Journal of Political Economy 88(6), 1110-1147.

Borjas, George J., Richard B. Freeman, and Lawrence F. Katz (1997). "How much do Immigration and Trade Affect Labor Market Outcomes?” Brookings Papers on Economic Activity 1, 1-90.

Cahuc, Pierre, Fabien Postel-Vinay, and Jean-Mark Robin (2006). "Wage Bargaining with onthe-Job Search: Theory and Evidence.” Econometrica 74(2), 323-364.

Corneo, Giacomo, and Rafael Robb (2003). "Working in Public and Private Firms.” Journal of Public Economics 87, 1335-1352.

Dickens, Richard, and Alan Manning (2004). "Spikes and Spill-Overs: The Impact of the National Minimum Wage on the Wage Distribution in a Low Wage Sector." Economic Journal 114, C95-C101.

Delfgaauw, Josse, and Robert Dur (2008). “Incentives and Workers' Motivation in the Public Sector.” Economic Journal 118(525), 171-191).

Demekas, Dimitri G., and Zenon G. Kontolemis (2000). “Government Employment and Wages and Labor Market Performance.” Oxford Bulletin of Economics and Statistics 62(3), 391-415. 
Driffield, Nigel, and Sourafel Girma (2003). "Regional Foreign Direct Investment and Wage Spillovers: Plant Level Evidence from the UK Electronics Industry”. Oxford Bulletin of Economics and Statistics 65(4), 453-474.

Du Caju, Philip, Gábor Kátay, Ana Lamo, Daphne Nicolitsas, and Steven Poelhekke (2010). "Inter-Industry Wage Differentials in EU Countries: What do Cross-Country Time Varying Data Add to the Picture?” Journal of the European Economic Association 8(2-3), 478-486.

Dustmann, Christian, and Arthur van Soest (1998). "Public and Private Wages of Male Workers in Germany.” European Economic Review 42, 1417-1441.

Earle, John S., Álmos Telegdy, and Gábor Antal (2012). „FDI and Wages: Evidence from Firm-Level and Linked Employer-Employee Data in Hungary, 1986-2008.” IZA Discussion Paper No. 7095.

Fabiani, Silvia, Kamil Galuscak, Claudia Kwapil, Ana Lamo, and Tairi Room (2010). "Wage Rigidities and Labor Market Adjustment in Europe." Journal of the European Economic Association 8(2-3), 497-505.

Farber, Henry S. (2005). "Nonunion Wage Rates and the Threat of Unionization.” Industrial and Labor Relations Review 58(3), 335-352.

Goette, Lorenz, Uwe Sunde, and Thomas Bauer (2007). "Wage Rigidity: Measurement, Causes and Consequences.” The Economic Journal 117(524). F499-F507.

Gorodnichenko, Yuriy, and Klara Sabirianova Peter (2007). "Public Sector Pay and Corruption: Measuring Bribery from Micro Data.” Journal of Public Economics 91, 963-991.

Gregory, Robert G., and Jeff Borland (1999). "Recent Developments in Public Sector Labor Markets.” In: Handbook of Labor Economics Vol. 3C (O. Ashenfelter, D. Card eds.), Amsterdam: Elsevier.

Gyourko, Joseph, and Joseph Tracy (1988). “An Analysis of Public- and Private-Sector Wages Allowing for Endogenous Choices of both Government and Union Status.” Journal of Labor Economics 6(2), 229-253.

Heywood, John S., W. S. Siebert, and Xiangdong Wei (2002). "Worker Sorting and Job Satisfaction: The Case of Union and Government Jobs." Industrial and Labor Relations Review 55(4), 595-609.

Hungarian Statistical Office, http://www.ksh.hu/docs/hun/xstadat/xstadat_eves/i_qli007.html

Jacobsen, Joyce (1992). "Spillover Effects from Government Employment." Economics Letters 39, 101-104.

Kahn, Lawrence M. (1998). “Collective Bargaining and the Interindustry Wage Structure: International Evidence.” Economica 65, 507-534.

Kambourov, Gueorgui, and Iourii Manovskii (2009). "Occupational Mobility and Wage Inequality.” Review of Economic Studies 76(2), 731-759.

Kertesi, Gábor, and János Köllő (2003). "Fighting 'low equilibria' by doubling the minimum wage? Hungary's experiment.” IZA Discussion Paper No. 970.

Krueger, Alan B., and Lawrence H. Summers (1988). "Efficiency Wages and the InterIndustry Wage Structure,” Econometrica, 56(2), 259-293. 
Lacroix, Robert, and Fancois Dussault (1984). "The Spillover Effect of Public-Sector Wage Contracts in Canada.” Review of Economics and Statistics 66(3), 509-512.

Lamo, Ana, Javier J. Pérez, and Ludger Schuknecht (2012). "Public or Private Wage Leadership? An International Perspective.” Scandinavian Journal of Economics 114(1), 228244.

Latreille, Paul L., and Neil Manning (2000). "Inter-Industry and Inter-Occupational Wage Spillovers in UK Manufacturing.” Oxford Bulletin of Economics and Statistics 62(1), 83-99.

Lee, David S. (1999). "Wage Inequality in the United States During the 1980s: Rising Dispersion of Falling Minimum Wage?” Quarterly Journal of Economics 114(3), 977-1023.

Manski, Charles (1993). "Identification of Endogenous Social Effects: The Reflection Problem. Review of Economic Studies 60, 531-542

Roy, Andrew. D. (1951). "Some Thoughts on the Distribution of Earnings." Oxford Economic Papers 3(2), 135-146.

Shleifer, Andrei, and Robert W. Vishny (1994). "Politicians and Firms.” Quarterly Journal of Economics, 109(4), 995-1025.

Tansel, Aysit (2005). "Public-Private Employment Choice, Wage Differentials, and Gender in Turkey.” Economic Development and Cultural Change 53(2), 453-477.

Teulings, Coen N. (2003). "The Contribution of Minimum Wages to Increasing Wage Inequality.” Economic Journal 113, 801-833.

Vroman, Wayne (1982). "Union Contracts and Money Wage Changes in U.S. Manufacturing Industries.” Quarterly Journal of Economics 97(4), 571-594. 
Table 1: Sample Size and Population of Public and Corporate Sectors

\begin{tabular}{|c|c|c|c|c|}
\hline \multirow[b]{2}{*}{ Year } & \multicolumn{2}{|c|}{ Public } & \multicolumn{2}{|c|}{ Corporate } \\
\hline & Sample & Population & Sample & Population \\
\hline 1998 & 378.8 & 719.0 & 105.8 & 1863.2 \\
\hline 1999 & 414.8 & 684.0 & 107.7 & 1849.4 \\
\hline 2000 & 412.6 & 671.0 & 125.8 & 1948.3 \\
\hline 2001 & 408.0 & 669.8 & 125.9 & 1952.7 \\
\hline 2002 & 426.1 & 678.9 & 133.8 & 1858.0 \\
\hline 2003 & 481.9 & 689.8 & 135.1 & 1859.5 \\
\hline 2004 & 486.9 & 686.7 & 149.1 & 1923.2 \\
\hline 2005 & 481.2 & 679.2 & 153.0 & 1888.0 \\
\hline 2006 & 478.7 & 647.2 & 149.4 & 1991.8 \\
\hline 2007 & 460.2 & 634.4 & 145.6 & 1930.6 \\
\hline
\end{tabular}


Table 2: Composition of the Workforce in the Public and Corporate Sectors

\begin{tabular}{|c|c|c|}
\hline & Public & Corporate \\
\hline \multicolumn{3}{|l|}{ Gender } \\
\hline Female & 73.5 & 39.7 \\
\hline \multicolumn{3}{|l|}{ Labor market experience } \\
\hline $0-5$ years & 5.0 & 6.2 \\
\hline 6-10 years & 8.9 & 13.1 \\
\hline 11-15 years & 10.3 & 13.3 \\
\hline $16-20$ years & 12.6 & 12.5 \\
\hline 21-25 years & 14.6 & 12.9 \\
\hline 26-30 years & 16.8 & 14.8 \\
\hline 31-35 years & 17.1 & 14.8 \\
\hline$>35$ years & 14.7 & 12.4 \\
\hline \multirow[t]{2}{*}{ Average experience } & 23.9 & 22.0 \\
\hline & $(10.6)$ & $(10.9)$ \\
\hline \multicolumn{3}{|l|}{ Occupation } \\
\hline Manager & 8.0 & 9.4 \\
\hline Professional & 31.0 & 5.0 \\
\hline Technician, associate professional & 28.4 & 15.0 \\
\hline Clerk & 6.5 & 6.6 \\
\hline Services worker & 6.6 & 10.4 \\
\hline Skilled worker & 6.0 & 45.4 \\
\hline Elementary occupation & 13.6 & 8.1 \\
\hline \multicolumn{3}{|l|}{ Tenure* } \\
\hline New hire & 9.2 & 13.6 \\
\hline \multirow[t]{2}{*}{ Tenure } & 13.0 & 9.4 \\
\hline & $(11.0)$ & $(11.0)$ \\
\hline $\mathrm{N}$ & $4,429,175$ & 1,331,012 \\
\hline $\begin{array}{l}\text { Notes: The figures refer to all years in th } \\
\text { except average experience and tenure (st } \\
\text { are weighted to correspond to the national } \\
* \text { *New hire is a dummy variable }=1 \text { if the } \\
\text { year. Tenure (measured in years) available }\end{array}$ & $\begin{array}{l}\text { a. All variabl } \\
\text { deviation in } \\
\text { my. } \\
\text { was hired dur } \\
\text { since } 2002 \text {. }\end{array}$ & $\begin{array}{l}\text { dummy variab } \\
\text { ses). The fig } \\
\text { previous calen }\end{array}$ \\
\hline
\end{tabular}


Figure 1: Wage Level and Growth in the Public and Corporate Sectors

Wage Level

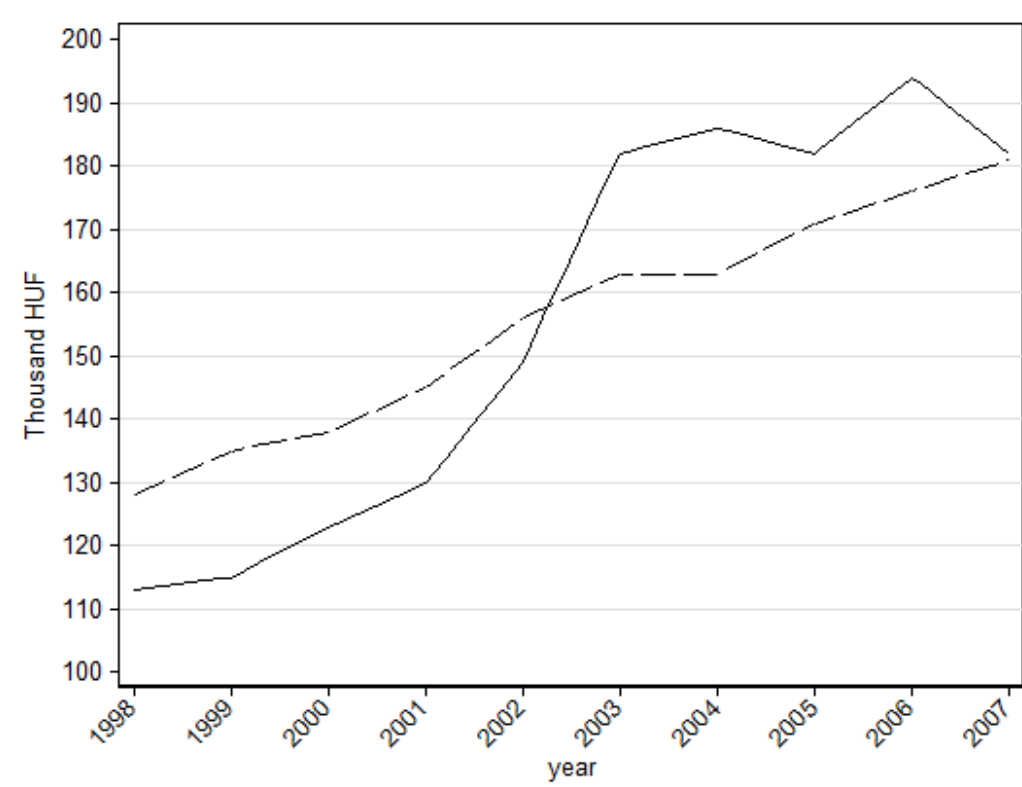

Wage Growth

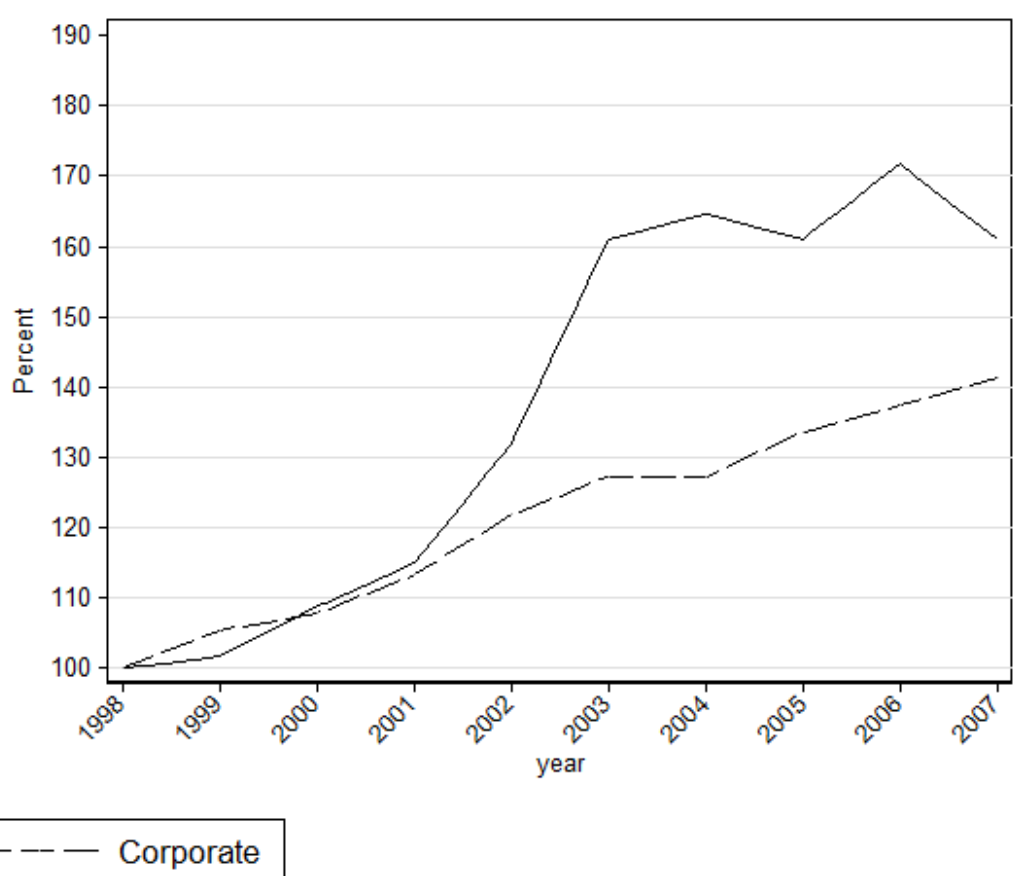

Notes: $\mathrm{N}=4,429,175$ (public sample); 1,331,012 (corporate sample). Wages expressed in thousands of 2007, deflated by the consumer price index. 
Figure 2: Evolution of the Public Wage Premium

Average Wage Premium

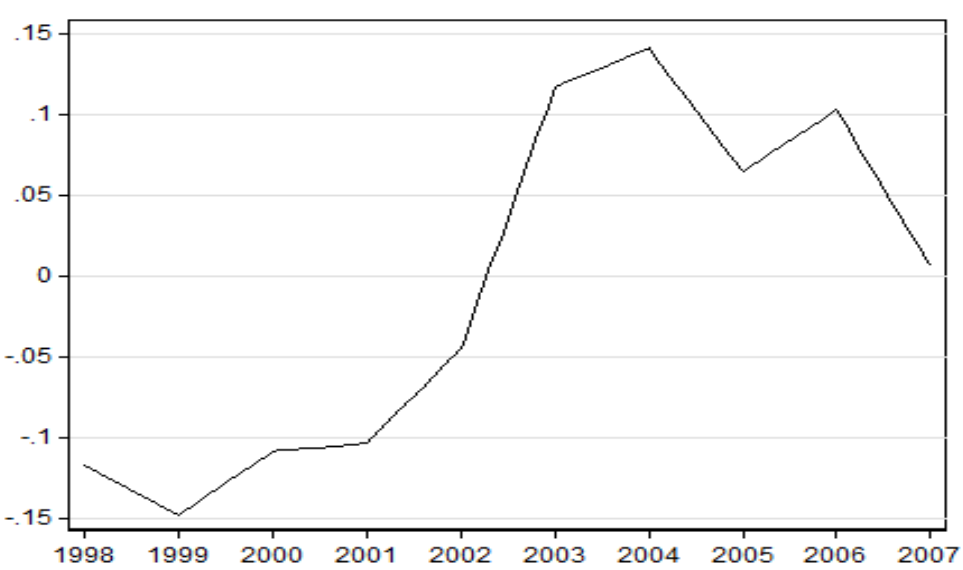

Wage Premium by Experience

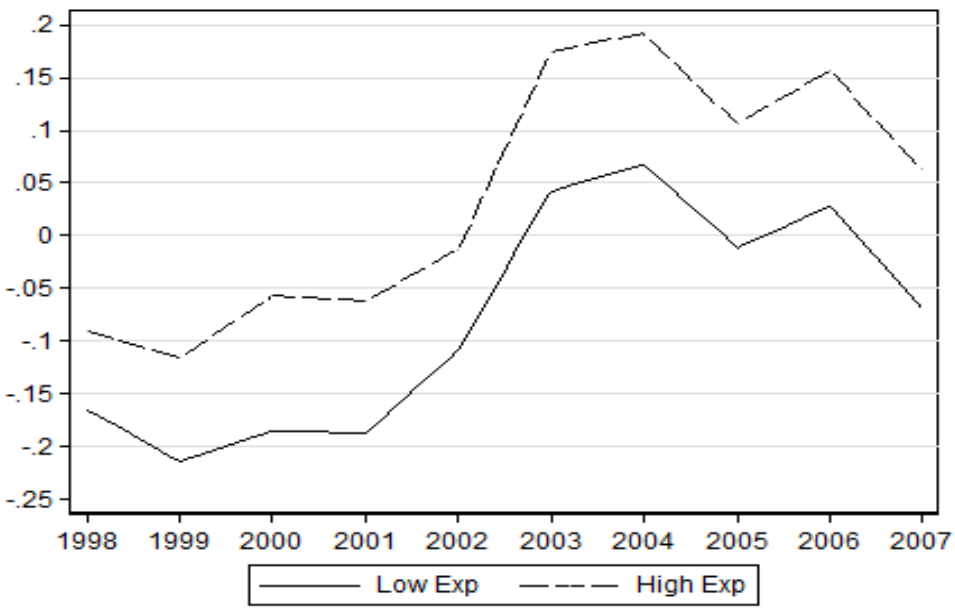

Wage Premium by Gender

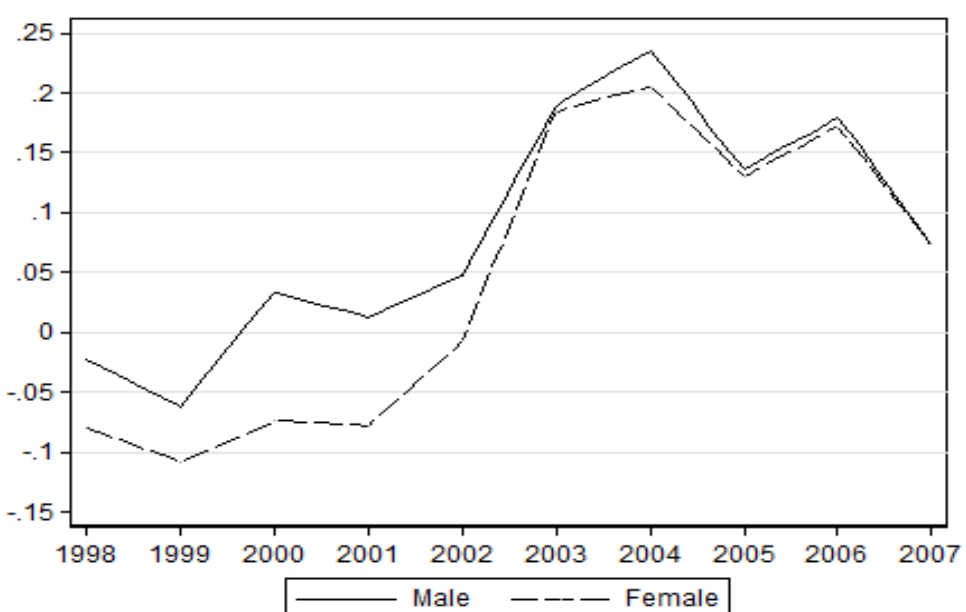

Wage Premium by Occupation

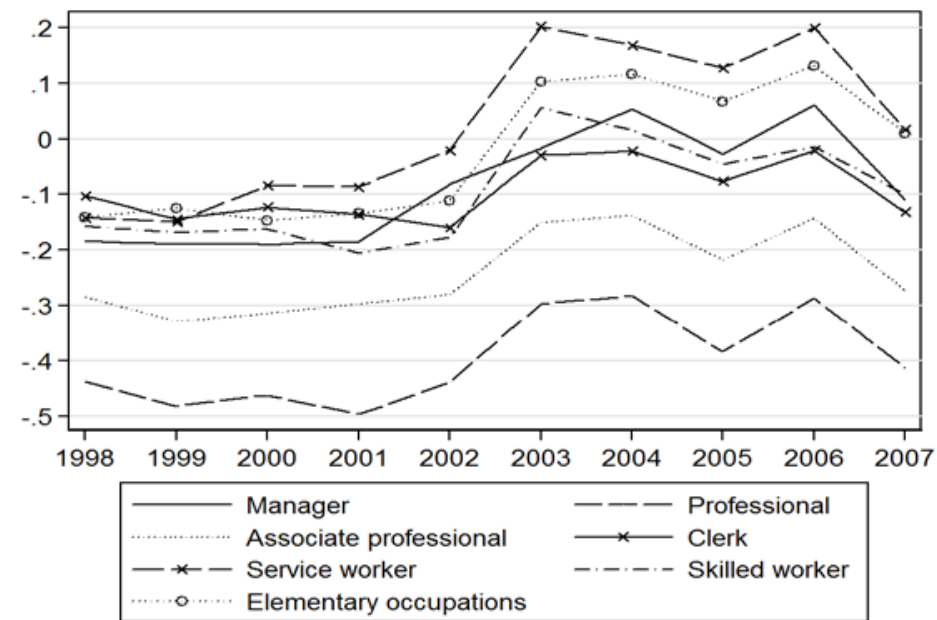

Notes: $\mathrm{N}=4,429,175$ (public sample); 1,331,012 (corporate sample). The figures represent the ratio of public and corporate wages by year and worker characteristics. 
Table 3: Share of Public Sector Workers in Labor Market Cells Defined by Gender, Experience and Occupation

\begin{tabular}{cllll}
\hline Year & Mean & Std. Dev & Min & Max \\
\hline 1998 & 0.21 & 0.20 & 0.01 & 0.96 \\
1999 & 0.20 & 0.19 & 0.01 & 0.97 \\
2000 & 0.19 & 0.19 & 0.01 & 0.93 \\
2001 & 0.19 & 0.19 & 0.01 & 0.92 \\
2002 & 0.20 & 0.19 & 0.01 & 0.92 \\
2003 & 0.21 & 0.19 & 0.01 & 0.85 \\
2004 & 0.20 & 0.19 & 0.00 & 0.87 \\
2005 & 0.20 & 0.19 & 0.01 & 0.93 \\
2006 & 0.19 & 0.18 & 0.00 & 0.88 \\
2007 & 0.19 & 0.19 & 0.00 & 0.89 \\
\hline
\end{tabular}

Notes: Unit of observation: 112 labor market cells each year defined by gender, experience and occupation. The variable is the share of public sector employment in these cells. 
Table 4: The Effect of Public Sector Exposure on Corporate Wages

\begin{tabular}{|c|c|c|c|c|}
\hline & OLS & OLS & FE & WE \\
\hline \multirow[t]{2}{*}{ Pshare*Before } & 0.020 & $-0.050 * *$ & 0.033 & $-0.106^{* *}$ \\
\hline & $(0.010)$ & $(0.011)$ & $(0.017)$ & $(0.016)$ \\
\hline \multirow[t]{2}{*}{ Pshare*After } & $0.136 * *$ & $0.127 * *$ & $0.163 * *$ & -0.021 \\
\hline & $(0.009)$ & $(0.010)$ & $(0.017)$ & $(0.016)$ \\
\hline \multirow{2}{*}{ Ln(Public Wage) } & & 0.021 & $0.077 * *$ & $0.123 * *$ \\
\hline & & $(0.014)$ & $(0.014)$ & $(0.008)$ \\
\hline \multirow{2}{*}{ Ln(Unemployment Rate) } & & $-0.167 * *$ & $-0.131 * *$ & $-0.005^{* *}$ \\
\hline & & $(0.002)$ & $(0.004)$ & $(0.002)$ \\
\hline \multirow[t]{2}{*}{ Female } & $-0.166^{* *}$ & $-0.136 * *$ & $-0.142 * *$ & - \\
\hline & $(0.002)$ & $(0.002)$ & $(0.005)$ & - \\
\hline \multirow[t]{2}{*}{ Exp 6-10 } & $0.094 * *$ & -0.007 & 0.004 & - \\
\hline & $(0.003)$ & $(0.004)$ & $(0.003)$ & - \\
\hline \multirow[t]{2}{*}{ Exp 11-15 } & $0.124 * *$ & -0.004 & $0.016 * *$ & - \\
\hline & $(0.003)$ & $(0.005)$ & $(0.004)$ & - \\
\hline \multirow{2}{*}{ Exp 16-20 } & $0.134 * *$ & -0.006 & $0.019 * *$ & - \\
\hline & $(0.003)$ & $(0.005)$ & $(0.005)$ & - \\
\hline \multirow[t]{2}{*}{ Exp 21-25 } & $0.144 * *$ & -0.003 & $0.028 * *$ & - \\
\hline & $(0.003)$ & $(0.006)$ & $(0.006)$ & - \\
\hline \multirow[t]{2}{*}{ Exp 26-30 } & $0.159 * *$ & 0.007 & $0.038 * *$ & - \\
\hline & $(0.003)$ & $(0.006)$ & $(0.009)$ & - \\
\hline \multirow[t]{2}{*}{ Exp 31-35 } & $0.164 * *$ & 0.004 & $0.034 * *$ & - \\
\hline & $(0.003)$ & $(0.006)$ & $(0.009)$ & - \\
\hline \multirow[t]{2}{*}{ Exp 36- } & $0.143^{* *}$ & $-0.041 * *$ & -0.009 & - \\
\hline & $(0.004)$ & $(0.007)$ & $(0.009)$ & - \\
\hline \multirow[t]{2}{*}{ Manager } & $0.972 * *$ & $0.734 * *$ & $0.669 * *$ & - \\
\hline & $(0.005)$ & $(0.019)$ & $(0.018)$ & - \\
\hline \multirow[t]{2}{*}{ Professional } & $0.975 * *$ & $0.674^{* *}$ & $0.450 * *$ & - \\
\hline & $(0.006)$ & $(0.015)$ & $(0.018)$ & - \\
\hline \multirow[t]{2}{*}{ Associate Prof. } & $0.518 * *$ & $0.359 * *$ & $0.269 * *$ & - \\
\hline & $(0.003)$ & $(0.009)$ & $(0.010)$ & - \\
\hline \multirow{2}{*}{ Clerk } & $0.367 * *$ & $0.228 * *$ & $0.193 * *$ & - \\
\hline & $(0.004)$ & $(0.006)$ & $(0.009)$ & - \\
\hline \multirow[t]{2}{*}{ Service Worker } & $0.160 * *$ & $0.083 * *$ & $0.118 * *$ & - \\
\hline & $(0.003)$ & $(0.004)$ & $(0.013)$ & - \\
\hline \multirow[t]{2}{*}{ Skilled worker } & $0.258 * *$ & $0.202 * *$ & $0.161 * *$ & - \\
\hline & $(0.003)$ & $(0.004)$ & $(0.009)$ & - \\
\hline $\mathrm{R}^{2}$ & 0.44 & 0.46 & 0.41 & 0.14 \\
\hline $\mathrm{N}$ & $1,331,012$ & $1,331,012$ & $1,329,273$ & 645,652 \\
\hline
\end{tabular}

Notes: Dependent variable: $\log$ (wage). „Before" = 1998 to 2001; "After" = 2002 to 2007. Each regression includes controls for year, industry, and region. Omitted categories: male, 0-5 years of experience, unskilled occupations. Robust standard errors in OLS, standard errors clustered at the firm (worker) level in FE (WE). ** = significant at the 1-percent level; ** = significant at the 5-percent level. 
Figure 3: Yearly Effect of Public Sector Exposure on Corporate Wages

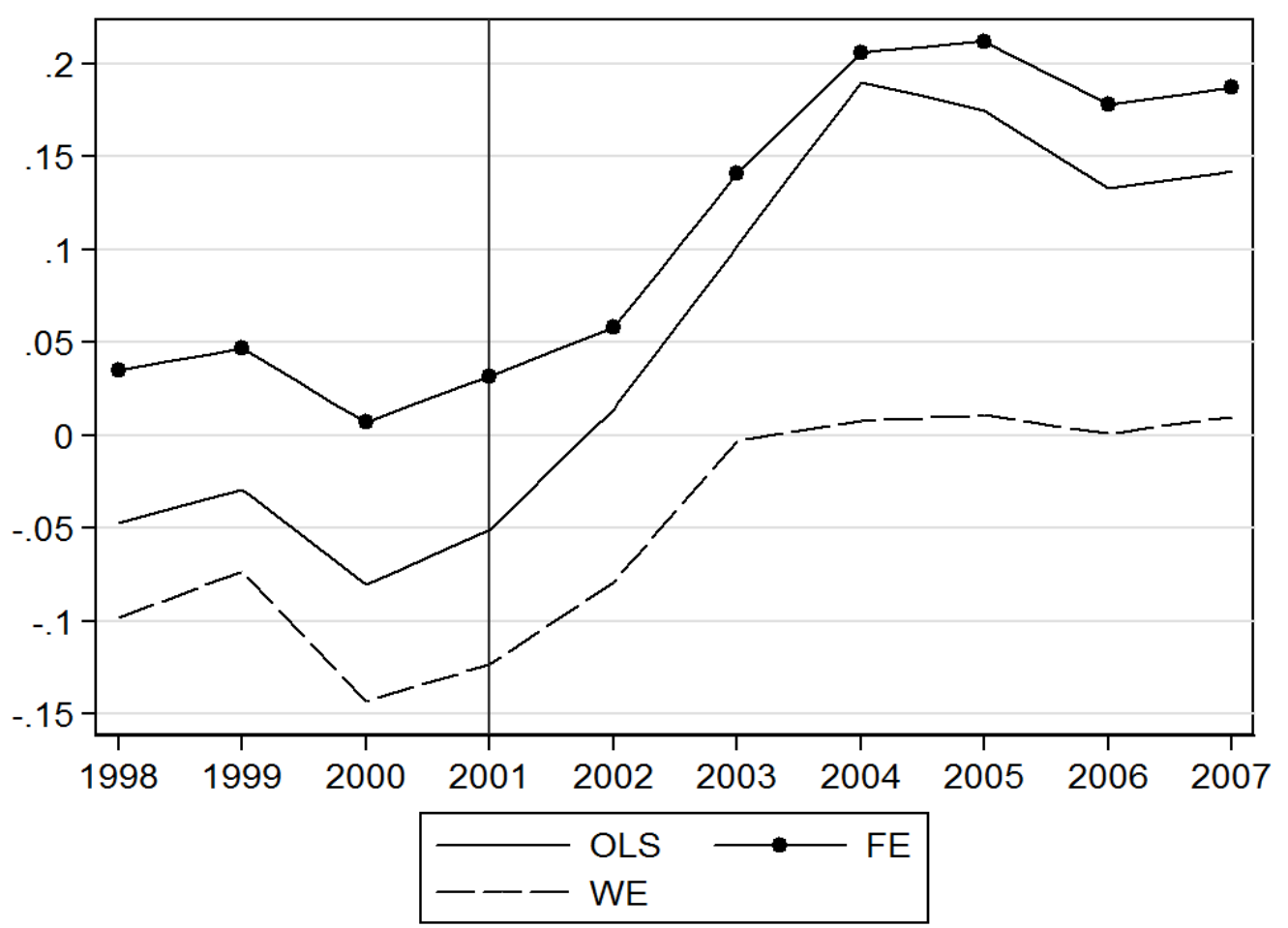

Notes: $\mathrm{N}=1,331,012$ (OLS), 1,329,273 (FE), 645,652 (WE). The figure plots the estimated coefficients of public sector share within labor market cells interacted with years. Dependent variable: log(wage). The OLS and FE regressions include controls for gender, experience, occupation and each regression controls for average public wage, the unemployment rate, year, industry, and region. The coefficients (standard errors) are presented in Appendix Table A3. 
Figure 4: The Effect of Public Sector Exposure on Corporate Wages: Differences Between Quintiles

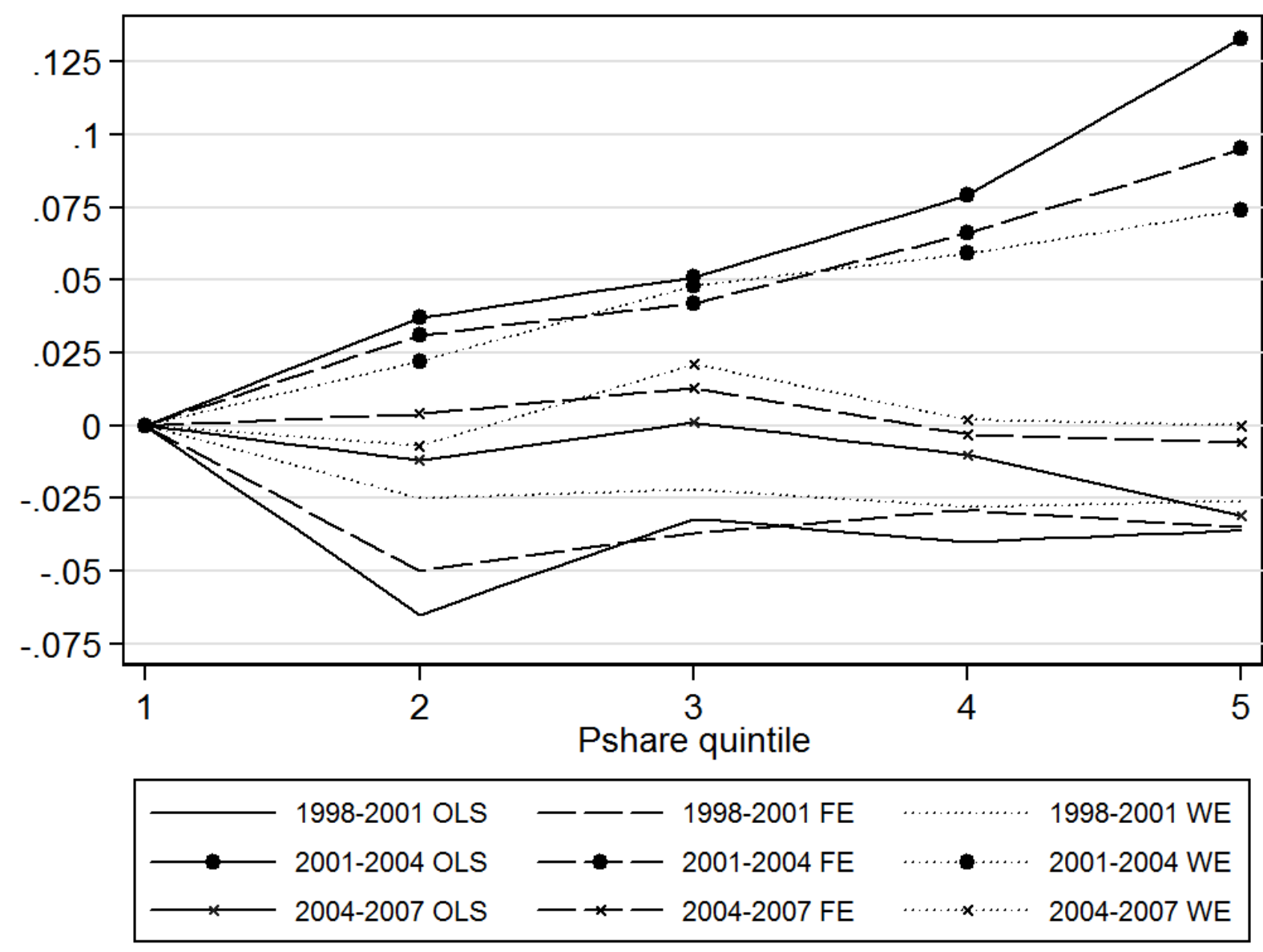

Notes: $\mathrm{N}=1,331,012$ (OLS), 1,329,273 (FE), 645,652 (WE). The figure shows the difference between the coefficients of each quintile of Pubshare for the period pre-public wage increase (1998-2001) during the wage increase (2001-2004) and after the wage increase (2004-2007). Dependent variable: log(wage). The OLS and FE regressions include controls for gender, experience, occupation and each regression controls for average public wage, the unemployment rate, year, industry, and region. The estimated coefficients (standard errors) are presented in Appendix Table A4. 
Table 5: Changes in the Gender Wage Gap, Skill Premium and Estimation without Workers at the Minimum Wage

\begin{tabular}{|c|c|c|c|}
\hline & \multicolumn{3}{|c|}{ Gender wage gap } \\
\hline & OLS & & FE \\
\hline \multirow[t]{2}{*}{ Female*Before } & $-0.165 * *$ & & $-0.156 * *$ \\
\hline & $(0.003)$ & & $(0.007)$ \\
\hline \multirow[t]{2}{*}{ Female*After } & $-0.113^{* *}$ & & $-0.120 * *$ \\
\hline & $(0.002)$ & & $(0.005)$ \\
\hline $\mathrm{R}^{2}$ & 0.46 & & 0.42 \\
\hline \multirow[t]{3}{*}{$\mathrm{N}$} & $1,331,012$ & & $1,329,273$ \\
\hline & \multicolumn{3}{|c|}{ Skill premium } \\
\hline & OLS & & FE \\
\hline \multirow[t]{2}{*}{ High Skill*Before } & $0.081 * *$ & & $0.112 * *$ \\
\hline & $(0.007)$ & & $(0.019)$ \\
\hline \multirow[t]{2}{*}{ High Skill*After } & $0.144^{* *}$ & & $0.146^{* *}$ \\
\hline & $(0.007)$ & & $(0.018)$ \\
\hline $\mathrm{R}^{2}$ & 0.45 & & 0.40 \\
\hline \multirow[t]{3}{*}{$\mathrm{N}$} & $1,331,012$ & & $1,329,273$ \\
\hline & \multicolumn{3}{|c|}{ Wage $>$ minimum wage } \\
\hline & OLS & $\mathbf{F E}$ & WE \\
\hline \multirow[t]{2}{*}{ Pshare*Before } & $-0.037 * *$ & $0.047^{*}$ & $-0.103 * *$ \\
\hline & $(0.010)$ & $(0.019)$ & $(0.017)$ \\
\hline \multirow[t]{2}{*}{ Pshare*After } & $0.107 * *$ & $0.183^{* *}$ & -0.023 \\
\hline & $(0.010)$ & $(0.019)$ & $(0.016)$ \\
\hline $\mathrm{R}^{2}$ & 0.48 & 0.44 & 0.15 \\
\hline $\mathrm{N}$ & $1,130,744$ & $1,128,011$ & 567,829 \\
\hline
\end{tabular}

Notes: Dependent variable: $\log ($ wage). „Before" $=1998$ to 2001; "After" = 2002 to 2007. Each regression includes controls for gender, experience, occupation, public sector wage, the unemployment rate, year, industry, and region. Robust standard errors in OLS, standard errors clustered at the firm (worker) level in FE (WE). ${ }^{* *}=$ significant at the 1-percent level; * = significant at the 5-percent level. 
Table 6: Public Wage Spillovers: Heterogeneity of Wage Spillovers by Public Wages, Occupation and Public Sector Vacancies

\begin{tabular}{lccc}
\hline & $\begin{array}{c}\text { X Mean } \\
\text { Public Wage }\end{array}$ & $\begin{array}{c}\text { X = Occupation } \\
\text { prevalent in } \\
\text { Public Sector }\end{array}$ & $\begin{array}{c}\text { X = Proportion } \\
\text { of pubic sector } \\
\text { vacancies }\end{array}$ \\
\hline & $0.190^{* *}$ & OLS \\
\hline Diff (Pshare After-Before) & $(0.000)$ & $(0.000)$ & $0.169^{* *}$ \\
& $0.074^{* *}$ & $0.073^{* *}$ & $(0.000)$ \\
Diff (Pshare*X After-Before) & $(0.018)$ & $(0.000)$ & $\left(0.0065^{* *}\right.$ \\
\hline & \multicolumn{3}{c}{ FE } \\
\hline Diff (Pshare After-Before) & $0.061^{* *}$ & $0.110^{* *}$ \\
& $(0.003)$ & $(0.000)$ & $0.120^{* *}$ \\
Diff (Pshare*X After-Before) & 0.029 & $0.075^{* *}$ & $0.000)$ \\
& $(0.236)$ & $(0.004)$ & $(0.057)$ \\
\hline
\end{tabular}

Notes: The table presents the differences between regression coefficients (the p-value corresponding to the test of equality of the coefficients in parentheses). "Before" = 1998 to 2001; "After" = 2002 to 2007. The regression coefficients are presented in Table A5.

${ }^{1} \mathrm{X}$ not interacted with Pshare. Proportion hired is measured relative to the size of the corporate sector. 
Table 7: The Effect of New Hiring on Wage Spillovers

\begin{tabular}{lcc}
\hline & \multicolumn{1}{c}{ OLS } & FE \\
\hline Pshare Before & $-0.054^{* *}$ & 0.031 \\
& $(0.011)$ & $(0.017)$ \\
Pshare After & $0.076^{* *}$ & $0.153^{* *}$ \\
& $(0.010)$ & $(0.017)$ \\
\hline Pshare * X After & $0.089^{* *}$ & -0.000 \\
& $(0.009)$ & $(0.017)$ \\
\hline $\mathrm{R}^{2}$ & 0.46 & 0.41 \\
\hline Diff (Pshare After-Before) & 0.13 & 0.122 \\
\hline
\end{tabular}

Notes: $N=1,331,012$ (OLS), 1,329,273 (FE). Dependent variable: log(wage). Each regression includes controls for gender, experience, occupation, public sector wage, the unemployment rate, year, industry, region. and the level of new hire variable. Robust standard errors in parentheses. ${ }^{* *}=$ significant at the 1-percent level. 
Appendix Tables and Figures

Table A1: Evolution of Worker Characteristics

\begin{tabular}{|c|c|c|c|c|c|c|c|c|c|c|}
\hline & \multicolumn{10}{|c|}{ Public } \\
\hline & 1998 & 1999 & 2000 & 2001 & 2002 & 2003 & 2004 & 2005 & 2006 & 2007 \\
\hline Female & 72.5 & 72.6 & 72.9 & 74.0 & 73.0 & 73.4 & 73.9 & 74.3 & 74.7 & 74.2 \\
\hline \multicolumn{11}{|l|}{ Experience } \\
\hline 0-5 years & 6.2 & 5.9 & 6.4 & 5.4 & 5.3 & 4.9 & 4.6 & 4.1 & 3.9 & 3.6 \\
\hline 6-10 years & 9.6 & 8.8 & 8.5 & 9.4 & 8.7 & 8.9 & 8.9 & 8.8 & 8.7 & 8.5 \\
\hline 11-15 years & 11.3 & 11.0 & 10.6 & 10.0 & 10.3 & 10.1 & 10.2 & 10.0 & 10.0 & 9.9 \\
\hline $16-20$ years & 13.4 & 12.4 & 13.1 & 12.7 & 12.4 & 12.4 & 12.5 & 12.6 & 12.5 & 12.5 \\
\hline 21-25 years & 16.5 & 15.4 & 15.0 & 14.9 & 14.2 & 14.1 & 13.8 & 13.9 & 14.0 & 14.3 \\
\hline 26-30 years & 18.3 & 18.4 & 17.4 & 17.1 & 16.9 & 16.3 & 15.9 & 15.9 & 15.6 & 15.7 \\
\hline 31-35 years & 16.0 & 16.2 & 17.3 & 17.1 & 17.4 & 17.4 & 17.3 & 17.3 & 17.3 & 17.3 \\
\hline$>35$ years & 8.6 & 11.9 & 11.8 & 13.5 & 14.8 & 16.0 & 16.8 & 17.5 & 18.1 & 18.2 \\
\hline \multicolumn{11}{|l|}{ Occupation } \\
\hline Manager & 8.2 & 7.8 & 8.5 & 8.3 & 8.0 & 7.8 & 7.7 & 7.8 & 7.8 & 7.6 \\
\hline Professional & 28.8 & 28.5 & 30.8 & 31.2 & 30.7 & 30.5 & 31.2 & 32.0 & 32.6 & 34.5 \\
\hline Assoc. Prof. & 28.8 & 27.4 & 29.0 & 29.3 & 27.9 & 28.3 & 28.4 & 28.0 & 28.7 & 27.8 \\
\hline Clerk & 5.7 & 5.6 & 6.0 & 6.0 & 5.9 & 6.2 & 7.7 & 7.7 & 7.2 & 6.6 \\
\hline Service worker & 7.0 & 7.5 & 6.4 & 6.7 & 6.8 & 6.8 & 6.5 & 6.3 & 6.4 & 6.0 \\
\hline Skilled worker & 6.5 & 6.9 & 5.9 & 5.6 & 6.8 & 6.1 & 5.6 & 5.5 & 5.2 & 5.4 \\
\hline Elem. Occup. & 15.1 & 16.4 & 13.4 & 13.0 & 14.0 & 14.4 & 13.0 & 12.7 & 12.2 & 12.0 \\
\hline \multirow[t]{2}{*}{$\mathrm{N}$ (thousands) } & 378.8 & 414.8 & 412.6 & 408.0 & 426.1 & 481.9 & 486.9 & 481.2 & 478.7 & 460.2 \\
\hline & & \multicolumn{9}{|c|}{ Corporate } \\
\hline Female & 38.9 & 39.0 & 39.6 & 39.6 & 39.1 & 40.2 & 40.4 & 39.7 & 40.9 & 39.9 \\
\hline \multicolumn{11}{|l|}{ Experience } \\
\hline $0-5$ years & 7.7 & 7.6 & 7.3 & 6.8 & 6.1 & 5.5 & 5.1 & 5.0 & 5.6 & 5.8 \\
\hline 6-10 years & 12.3 & 13.1 & 13.4 & 13.5 & 13.9 & 13.1 & 13.3 & 13.4 & 13.2 & 12.2 \\
\hline 11-15 years & 11.8 & 12.1 & 12.2 & 12.5 & 13.0 & 13.1 & 14.0 & 14.4 & 14.7 & 14.7 \\
\hline $16-20$ years & 12.0 & 11.4 & 11.4 & 11.8 & 12.4 & 12.7 & 13.1 & 13.4 & 13.4 & 13.7 \\
\hline 21-25 years & 15.1 & 13.8 & 13.2 & 13.0 & 12.2 & 12.3 & 12.1 & 12.3 & 12.5 & 12.6 \\
\hline 26-30 years & 18.0 & 17.1 & 16.7 & 16.1 & 15.2 & 14.3 & 13.4 & 12.7 & 12.3 & 12.3 \\
\hline 31-35 years & 14.4 & 14.9 & 15.2 & 15.0 & 15.3 & 15.7 & 15.1 & 14.9 & 14.2 & 13.6 \\
\hline$>35$ years & 8.8 & 10.1 & 10.6 & 11.5 & 12.1 & 13.3 & 14.0 & 14.0 & 14.2 & 15.2 \\
\hline \multicolumn{11}{|l|}{ Occupation } \\
\hline Manager & 10.3 & 10.6 & 9.9 & 9.3 & 9.3 & 8.9 & 9.0 & 9.2 & 9.8 & 8.3 \\
\hline Professional & 3.8 & 3.8 & 4.1 & 4.2 & 4.6 & 6.0 & 5.9 & 5.2 & 6.9 & 5.8 \\
\hline Assoc. Prof. & 14.2 & 13.8 & 13.5 & 14.3 & 14.4 & 15.1 & 15.6 & 15.8 & 17.0 & 16.2 \\
\hline Clerk & 7.1 & 7.4 & 6.8 & 6.9 & 6.2 & 6.3 & 6.2 & 6.3 & 6.6 & 6.0 \\
\hline Service worker & 8.6 & 9.1 & 9.7 & 9.8 & 10.0 & 10.3 & 11.3 & 11.3 & 11.9 & 12.2 \\
\hline Skilled worker & 48.3 & 47.4 & 48.1 & 47.9 & 47.5 & 45.1 & 43.4 & 44.2 & 39.9 & 43.1 \\
\hline Elem. Occup. & 7.8 & 8.0 & 8.0 & 7.7 & 8.1 & 8.4 & 8.6 & 8.1 & 8.1 & 8.5 \\
\hline $\mathrm{N}$ (thousands) & 105.8 & 107.7 & 125.8 & 125.9 & 133.8 & 135.1 & 149.1 & 153.0 & 149.4 & 145.6 \\
\hline
\end{tabular}


Figure A1: Public Sector Employment Share in Gender-Experience-Occupation Cells

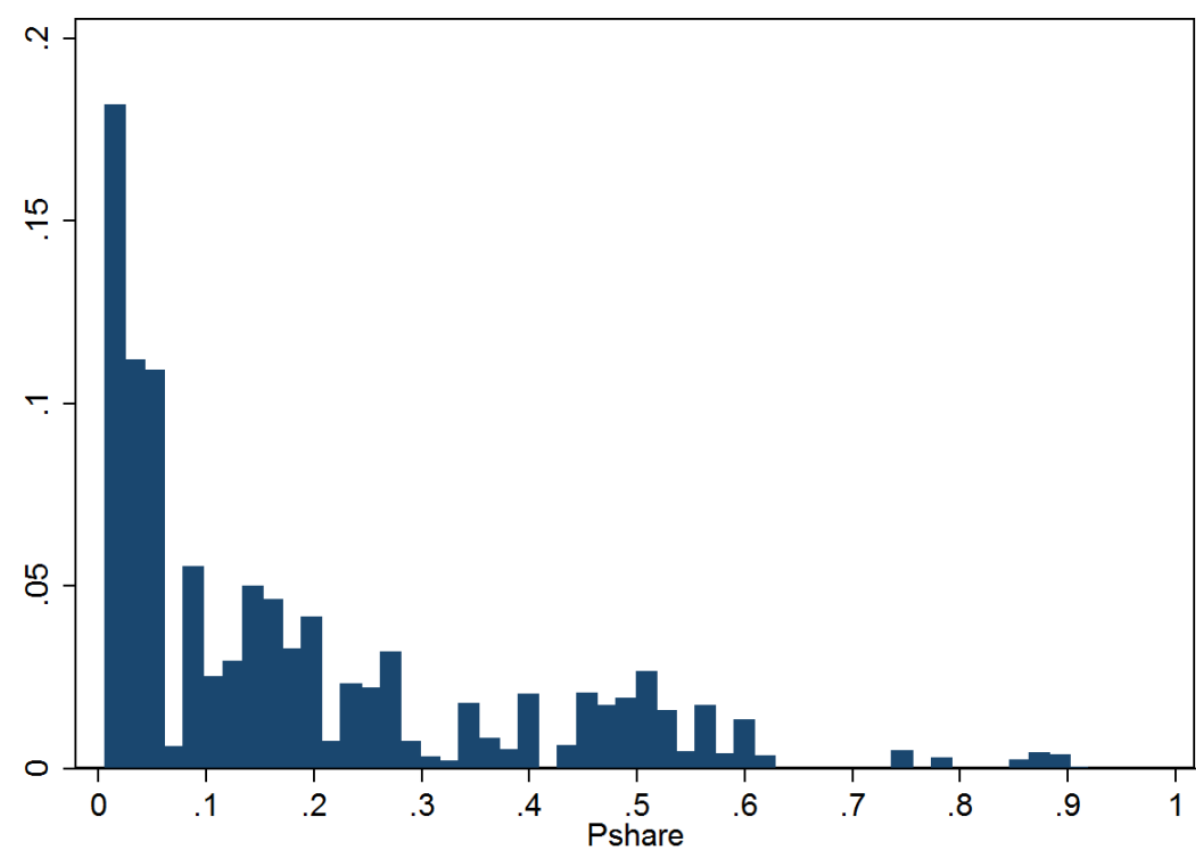

Notes: $N=125,850$. The variable represents the share of public sector employment in 2001 in labor market cells defined by 2 genders, 8 experience categories (5 years long each) and 7 occupational categories. 
Table A2: Composition of Sectors by Pshare in 2001

\begin{tabular}{|c|c|c|c|c|c|c|c|c|}
\hline \multirow{2}{*}{ Pshare } & \multirow{2}{*}{ Female } & \multirow{2}{*}{ Exp } & \multicolumn{2}{|c|}{ 1st occup } & \multicolumn{2}{|c|}{ 2nd occup } & \multirow{2}{*}{$\begin{array}{l}\text { Number } \\
\text { of Cells }\end{array}$} & \multirow{2}{*}{$\begin{array}{c}\text { Number of } \\
\text { Observations }\end{array}$} \\
\hline & & & Category & $\%$ & Category & $\%$ & & \\
\hline $0-10$ & 24.5 & 21.2 & $\begin{array}{l}\text { Skilled } \\
\text { worker }\end{array}$ & 92.5 & Manager & 3.6 & 24 & 58347 \\
\hline $10-20$ & 20.3 & 18.3 & Manager & 30.6 & $\begin{array}{l}\text { Service } \\
\text { worker }\end{array}$ & 27.6 & 31 & 26308 \\
\hline $20-30$ & 56.4 & 28.4 & Clerk & 41.1 & $\begin{array}{c}\text { Associate } \\
\text { professional }\end{array}$ & 29.6 & 17 & 13396 \\
\hline $30-40$ & 73.7 & 17.8 & Professional & 26.3 & Manager & 26.2 & 10 & 6234 \\
\hline $40-50$ & 93.2 & 21.2 & $\begin{array}{c}\text { Associate } \\
\text { professional }\end{array}$ & 62.5 & Manager & 22.3 & 9 & 8734 \\
\hline $50-60$ & 83.0 & 26.0 & $\begin{array}{c}\text { Associate } \\
\text { professional }\end{array}$ & 55.7 & $\begin{array}{l}\text { Unskilled } \\
\text { worker }\end{array}$ & 27.3 & 10 & 9332 \\
\hline$<60$ & 83.8 & 24.1 & Professional & 75.5 & $\begin{array}{c}\text { Associate } \\
\text { professional }\end{array}$ & 24.5 & 11 & 3499 \\
\hline
\end{tabular}


Table A3: Yearly Effect of Public Sector Exposure on Corporate Wages

\begin{tabular}{llcl}
\hline & OLS & FE & \multicolumn{1}{c}{ WE } \\
\hline 1998 & $-0.047^{* *}$ & 0.035 & $-0.098^{* *}$ \\
& $(0.017)$ & $(0.022)$ & $(0.018)$ \\
1999 & -0.029 & $0.047^{*}$ & $-0.073^{* *}$ \\
& $(0.016)$ & $(0.019)$ & $(0.017)$ \\
2000 & $-0.080^{* *}$ & 0.007 & $-0.143^{* *}$ \\
& $(0.017)$ & $(0.018)$ & $(0.018)$ \\
2001 & $-0.051^{* *}$ & 0.032 & $-0.123^{* *}$ \\
& $(0.015)$ & $(0.019)$ & $(0.017)$ \\
2002 & 0.014 & $0.058^{* *}$ & $-0.079^{* *}$ \\
& $(0.012)$ & $(0.018)$ & $(0.016)$ \\
2003 & $0.102^{* *}$ & $0.141^{* *}$ & -0.003 \\
& $(0.013)$ & $(0.019)$ & $(0.016)$ \\
2004 & $0.190^{* *}$ & $0.206^{* *}$ & 0.008 \\
& $(0.013)$ & $(0.018)$ & $(0.017)$ \\
2005 & $0.175^{* *}$ & $0.212^{* *}$ & 0.011 \\
& $(0.014)$ & $(0.019)$ & $(0.016)$ \\
2006 & $0.133^{* *}$ & $0.178^{* *}$ & 0.001 \\
& $(0.015)$ & $(0.018)$ & $(0.018)$ \\
2007 & $0.142^{* *}$ & $0.187^{* *}$ & 0.010 \\
& $(0.013)$ & $(0.031)$ & $(0.021)$ \\
\hline $\mathrm{R}^{2}$ & 0.46 & 0.41 & 0.14 \\
$\mathrm{~N}$ & $1,331,012$ & $1,329,273$ & 645,652 \\
\hline
\end{tabular}

Notes: Dependent variable: $\log ($ wage). The coefficients represent interactions between Pshare and year dummies. The OLS and FE regressions include controls for gender, experience, occupation and each regression controls for average public wage, the unemployment rate, year, industry, and region. Robust standard errors in OLS, standard errors clustered at the firm (worker) level in FE (WE). ${ }^{* *}=$ significant at the 1percent level; * = significant at the 5-percent level. 
Table A4: The Effect of Public Sector Exposure on Corporate Wages by Quintiles of Pshare

\begin{tabular}{|c|c|c|c|c|c|c|c|c|c|c|}
\hline & 1998 & 1999 & 2000 & 2001 & 2002 & 2003 & 2004 & 2005 & 2006 & 2007 \\
\hline \multicolumn{11}{|l|}{ OLS } \\
\hline Pshare * 2nd quintile & $\begin{array}{l}0.117 * * \\
(0.006)\end{array}$ & $\begin{array}{l}0.086 * * \\
(0.006)\end{array}$ & $\begin{array}{l}0.077 * * \\
(0.006)\end{array}$ & $\begin{array}{l}0.052 * * \\
(0.005)\end{array}$ & $\begin{array}{l}0.042 * * \\
(0.005)\end{array}$ & $\begin{array}{l}0.092 * * \\
(0.005)\end{array}$ & $\begin{array}{l}0.089 * * \\
(0.005)\end{array}$ & $\begin{array}{l}0.074^{* *} \\
(0.006)\end{array}$ & $\begin{array}{l}0.042^{* *} \\
(0.005)\end{array}$ & $\begin{array}{l}0.077^{* *} \\
(0.005)\end{array}$ \\
\hline Pshare * 3rd quintile & $\begin{array}{l}0.092 * * \\
(0.008)\end{array}$ & $\begin{array}{l}0.076 * * \\
(0.010)\end{array}$ & $\begin{array}{l}0.047 * * \\
(0.007)\end{array}$ & $\begin{array}{l}0.060 * * \\
(0.008)\end{array}$ & $\begin{array}{l}0.075^{* *} \\
(0.006)\end{array}$ & $\begin{array}{l}0.108^{* *} \\
(0.007)\end{array}$ & $\begin{array}{l}0.111^{* *} \\
(0.007)\end{array}$ & $\begin{array}{l}0.102 * * \\
(0.007)\end{array}$ & $\begin{array}{l}0.046^{* *} \\
(0.008)\end{array}$ & $\begin{array}{l}0.112 * * \\
(0.007)\end{array}$ \\
\hline Pshare * 4th quintile & $\begin{array}{l}0.114 * * \\
(0.011)\end{array}$ & $\begin{array}{l}0.085^{* *} \\
(0.010)\end{array}$ & $\begin{array}{l}0.072 * * \\
(0.009)\end{array}$ & $\begin{array}{l}0.074 * * \\
(0.009)\end{array}$ & $\begin{array}{l}0.089 * * \\
(0.007)\end{array}$ & $\begin{array}{l}0.142 * * \\
(0.007)\end{array}$ & $\begin{array}{l}0.153^{* *} \\
(0.008)\end{array}$ & $\begin{array}{l}0.132^{* *} \\
(0.008)\end{array}$ & $\begin{array}{l}0.089 * * \\
(0.008)\end{array}$ & $\begin{array}{l}0.143 * * \\
(0.007)\end{array}$ \\
\hline Pshare $*$ 5th quintile & $\begin{array}{l}0.072 * * \\
(0.010)\end{array}$ & $\begin{array}{l}0.065 * * \\
(0.009)\end{array}$ & $\begin{array}{l}0.036 * * \\
(0.009)\end{array}$ & $\begin{array}{l}0.036^{* *} \\
(0.009)\end{array}$ & $\begin{array}{l}0.068 * * \\
(0.008)\end{array}$ & $\begin{array}{l}0.124 * * \\
(0.008)\end{array}$ & $\begin{array}{l}0.169 * * \\
(0.008)\end{array}$ & $\begin{array}{l}0.156^{* *} \\
(0.008)\end{array}$ & $\begin{array}{l}0.108 * * \\
(0.008)\end{array}$ & $\begin{array}{l}0.138^{* *} \\
(0.008)\end{array}$ \\
\hline \multicolumn{11}{|c|}{$\mathrm{N}=1,331,012 ; \mathrm{R}^{2}=0.46$} \\
\hline \multicolumn{11}{|l|}{ FE } \\
\hline Pshare $*$ 2nd quintile & $\begin{array}{l}0.083 * * \\
(0.008)\end{array}$ & $\begin{array}{l}0.072 * * \\
(0.009)\end{array}$ & $\begin{array}{l}0.052 * * \\
(0.007)\end{array}$ & $\begin{array}{l}0.033^{* *} \\
(0.006)\end{array}$ & $\begin{array}{l}0.023^{* *} \\
(0.005)\end{array}$ & $\begin{array}{l}0.064^{* *} \\
(0.006)\end{array}$ & $\begin{array}{l}0.064 * * \\
(0.007)\end{array}$ & $\begin{array}{l}0.064 * * \\
(0.006)\end{array}$ & $\begin{array}{l}0.029 * * \\
(0.005)\end{array}$ & $\begin{array}{l}0.068^{* *} \\
(0.006)\end{array}$ \\
\hline Pshare * 3rd quintile & $\begin{array}{l}0.067 * * \\
(0.008)\end{array}$ & $\begin{array}{l}0.071 * * \\
(0.008)\end{array}$ & $\begin{array}{l}0.027 * * \\
(0.007)\end{array}$ & $\begin{array}{l}0.030 * * \\
(0.009)\end{array}$ & $\begin{array}{l}0.045^{* *} \\
(0.008)\end{array}$ & $\begin{array}{l}0.066^{* *} \\
(0.007)\end{array}$ & $\begin{array}{l}0.072^{* *} \\
(0.007)\end{array}$ & $\begin{array}{l}0.084 * * \\
(0.007)\end{array}$ & $\begin{array}{l}0.024 * * \\
(0.007)\end{array}$ & $\begin{array}{l}0.085^{* *} \\
(0.010)\end{array}$ \\
\hline Pshare * 4th quintile & $\begin{array}{l}0.072 * * \\
(0.011)\end{array}$ & $\begin{array}{l}0.063 * * \\
(0.011)\end{array}$ & $\begin{array}{l}0.037 * * \\
(0.009)\end{array}$ & $\begin{array}{l}0.043 * * \\
(0.009)\end{array}$ & $\begin{array}{l}0.044^{* *} \\
(0.008)\end{array}$ & $\begin{array}{l}0.092 * * \\
(0.008)\end{array}$ & $\begin{array}{l}0.109 * * \\
(0.008)\end{array}$ & $\begin{array}{l}0.100 * * \\
(0.009)\end{array}$ & $\begin{array}{l}0.061 * * \\
(0.008)\end{array}$ & $\begin{array}{l}0.106 * * \\
(0.012)\end{array}$ \\
\hline Pshare * 5th quintile & $\begin{array}{l}0.062 * * \\
(0.013)\end{array}$ & $\begin{array}{l}0.062 * * \\
(0.011)\end{array}$ & $\begin{array}{l}0.028 * * \\
(0.011)\end{array}$ & $\begin{array}{l}0.027 * \\
(0.012)\end{array}$ & $\begin{array}{l}0.040 * * \\
(0.010)\end{array}$ & $\begin{array}{l}0.092^{* *} \\
0.064 * *\end{array}$ & $\begin{array}{l}0.122 * * \\
(0.009)\end{array}$ & $\begin{array}{l}0.132 * * \\
(0.011)\end{array}$ & $\begin{array}{l}0.086 * * \\
(0.009)\end{array}$ & $\begin{array}{l}0.116^{* *} \\
(0.017)\end{array}$ \\
\hline
\end{tabular}


Table A4 continued

\section{8}

\section{9}

2000

2001

2002

2003

2004

2005

2006

\section{WE}

Pshare * 2nd quintile

$0.016 * *$

$0.014^{* *}$

$-0.002$

$-0.009$

$-0.004$

0.002

$0.013^{* *}$

$0.015 * *$

$-0.001$

0.006

Pshare * 3rd quintile

(0.006)

(0.005)

(0.005)

(0.005)

(0.004)

(0.004)

(0.004)

(0.004)

(0.004)

(0.005)

$-0.012$

$-0.006$

$-0.042 * *$

$-0.034 * *$

$-0.018 * *$

0.005

$0.014 * *$

$0.013 *$

$-0.007$

$0.035 * *$

Pshare * 4th quintile

$-0.016 * \quad-0.010$

$-0.049 * *$

$-0.044^{* *}$

(0.006)

(0.005)

(0.005)

(0.005)

(0.006)

(0.008)

(0.007)

(0.007)

(0.006)

(0.006)

$-0.023 * *$

0.009

$0.015 *$

0.011

$-0.006$

0.017

Pshare * 5th quintile

$-0.043 * *$

$-0.031^{* *}$

$-0.075 * *$

$-0.069 * *$

$-0.047^{* *}$

(0.006)

(0.006)

(0.006)

(0.007)

(0.009)

(0.009)

(0.008)

(0.008)

(0.007)

(0.007)

$-0.005$

0.005

0.010

$-0.006$

-0.006
$(0.007)$

0.005

$\mathrm{N}=645,652 ; \mathrm{R}^{2}=0.14$

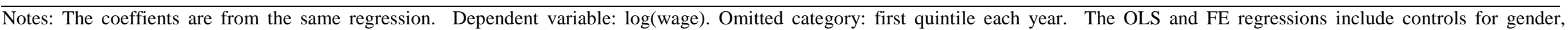

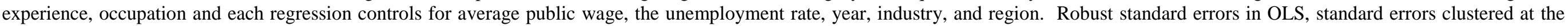
firm (worker) level in FE (WE). ** = significant at the 1-percent level; * = significant at the 5-percent level. 
Table A5: Public Wage Spillovers: Heterogeneity by Public Wages, Occupation and Public Sector Vacancies

\begin{tabular}{|c|c|c|c|}
\hline & (1) & (2) & (3) \\
\hline & $\begin{array}{c}\mathrm{X}=\underset{\text { Mean Public }}{\text { Wage }}\end{array}$ & $\begin{array}{c}\mathrm{X}=1 \text { if } \\
\text { Occupation } \\
\text { prevalent in } \\
\text { Public Sector }\end{array}$ & $\begin{array}{c}\mathrm{X}=\text { proportion of } \\
\text { pubic sector } \\
\text { vacancies }^{1}\end{array}$ \\
\hline & \multicolumn{3}{|c|}{ OLS } \\
\hline \multirow[t]{2}{*}{ Pshare Before } & $-0.058 * *$ & 0.002 & -0.020 \\
\hline & $(0.016)$ & $(0.012)$ & $(0.012)$ \\
\hline \multirow[t]{2}{*}{ Pshare After } & $0.132 * *$ & $0.150 * *$ & $0.149 * *$ \\
\hline & $(0.009)$ & $(0.010)$ & $(0.011)$ \\
\hline \multirow[t]{2}{*}{ Pshare * X Before } & -0.006 & $-0.171^{* *}$ & -0.006 \\
\hline & $(0.029)$ & $(0.015)$ & $(0.014)$ \\
\hline \multirow[t]{2}{*}{ Pshare $*$ X After } & $0.068 * *$ & $-0.098 * *$ & $0.059 * *$ \\
\hline & $(0.018)$ & $(0.014)$ & $(0.017)$ \\
\hline $\mathrm{R}^{2}$ & 0.46 & 0.46 & 0.45 \\
\hline \multirow[t]{2}{*}{$\mathrm{N}$} & $1,331,012$ & $1,331,012$ & $1,070,850$ \\
\hline & \multicolumn{3}{|c|}{ FE } \\
\hline \multirow[t]{2}{*}{ Pshare Before } & $0.094 * *$ & $0.079 * *$ & $0.055 * *$ \\
\hline & (0.019) & $(0.020)$ & $(0.017)$ \\
\hline \multirow[t]{2}{*}{ Pshare After } & $0.155^{* *}$ & $0.189 * *$ & $0.175^{* *}$ \\
\hline & $(0.017)$ & (0.019) & $(0.017)$ \\
\hline \multirow[t]{2}{*}{ Pshare * X Before } & $0.244 * *$ & $-0.144 * *$ & -0.006 \\
\hline & $(0.029)$ & $(0.024)$ & $(0.009)$ \\
\hline \multirow[t]{2}{*}{ Pshare $*$ X After } & $0.273 * *$ & $-0.069 * *$ & 0.021 \\
\hline & $(0.026)$ & $(0.021)$ & $(0.011)$ \\
\hline $\mathrm{R}^{2}$ & 0.41 & 0.41 & 0.41 \\
\hline $\mathrm{N}$ & $1,329,273$ & $1,329,273$ & $1,069,373$ \\
\hline
\end{tabular}

Notes: Dependent variable: $\log ($ wage). Each regression includes controls for gender, experience, occupation, average public wage, the unemployment rate, year, industry, and region as well as the level of X interacted with „Before” and "After.” Robust standard errors in the OLS regression, standard errors clustered at the firm level in the fixed-effects regression. ${ }^{* *}=$ significant at the 1 percent level. 